\title{
AS DESAPROPRIAÇÕES E DESPOSSESSÕES DE TERRAS PARA A IMPLANTAÇÃO DE PALMAS, A CAPITAL PROJETADA DO ESTADO DO TOCANTINS (BRASIL)
}

\author{
THE EXPROPRIATION AND DEPOSSESSIONS OF LANDS FOR THE \\ IMPLEMENTATION OF PALMAS, THE PROJECTED CAPITAL OF THE \\ STATE OF TOCANTINS (BRAZIL)
}

\section{LAS DESAPROPRACCIONES Y DESPOSSIONES DE TIERRAS PARA LA IMPLANTACIÓN DE PALMAS, LA CAPITAL PROYECTADA DEL ESTADO DEL TOCANTINS (BRASIL)}

\author{
Andreia Cristina Guimarães Cantuaria Lucini \\ Professora Doutora do Instituto Federal do Tocantins (IFTO), campus de Palmas. \\ E-mail:andreiacantuaria@hotmail.com
}

\section{Kelly Bessa}

Professora Doutora dos cursos de Geografia e dos Programas de Pós-Graduação em Geografia e Ciências do Ambiente da Universidade Federal do Tocantins (UFT).E-mail: kellybessa@uft.edu.br

\section{Resumo}

Com a instauração do estado do Tocantins, em 1989, o seu primeiro governo eleito delibera em favor da edificação de uma cidade, Palmas, para ser a capital estadual. Para tanto, fazia-se necessário selecionar o sítio e, na sequência, desapropriar as terras necessárias à implantação dessa capital. Paralelamente às ações de desapropriação, o governo lança mão de atos despossessórios arbitrários e abusivos, com a apoderação das terras implicadas. Esta pesquisa tem como objetivo compreender o imbróglio que envolveu as desapropriações e as despossessões de terras para a implantação de Palmas, a capital projetada do estado do Tocantins (Brasil), enfatizando-se os papéis dos governos estaduais e dos moradores da área atingida. Os procedimentos de análise fundamentaram-se em pesquisas bibliográfica, documental e de campo. Após anos de lutas, os expropriados tiveram suas demandas alcançadas, com a devolução de suas terras e com justas indenizações.

Palavras-chave: terras, desapropriações, despossessões, Palmas, estado do Tocantins.

\section{Abstract}

The first elected government of Tocantins, after the creation of this new Brazilian state, in 1989, rule in favor of the construction of a city, Palmas, to be the capital of the state. In order to accomplish it, it was essential to choose a site and, subsequently, to expropriate lands needed for creating the capital. In parallel with the expropriation actions, use arbitrary and abusive dispossessions, with the appropriation of the lands involved. This research 
had as objective to understand the imbroglio that involved the expropriations and the dispossessions of lands for the implantation of Palmas, the projected capital of Tocantins state (Brazil), the roles of the state government and the residents of the affected area were emphasized. The analysis procedures were based on bibliography, documents and field research. After years of struggle, the expropriated had their demands achieved, which resulted in the return of their lands and the due and fair monetary reparations.

Keywords: lands, expropriation, dispossession, city of Palmas, state of Tocantins/Brazil.

\section{Resumen}

Con la instauración del estado de Tocantins, en 1989, su primer gobierno electo delibera a favor de la edificación de una ciudad, Palmas, para ser la capital del estado. Para tanto, era imprescindible seleccionar el sitio y, en la secuencia, desapropiar las tierras necesarias a la implantación de esa capital. Paralelamente a las acciones de desapropiación, recurre a actos arbitrarios y abusivos, con el apoderamiento de las tierras implicadas. Esta investigación tiene como objetivo comprender esta confusión que envolvió las desapropiaciones y las desposesiones de tierras para la implantación de Palmas, la capital proyectada del estado de Tocantins, enfatizándose los papeles de los gobiernos estaduales y de los moradores del área alcanzada. Los procedimientos de análisis se fundamentaron en investigaciones bibliográfica, documental y de campo. Después de años de luchas, los expropiados tuvieron sus demandas alcanzadas, la devolución de sus tierras y las debidas y justas indemnizaciones.

Palabras-clave: tierras, desapropiación, desposesión, ciudad de Palmas, estado de Tocantins/ Brasil. 


\section{Introdução}

Na recém-criada capital do estado do Tocantins, cabe a analogia com a questão de Marx (1991): cidade de Palmas, terra de quem? ${ }^{1}$ Em 1989, com a criação desse estado, o seu primeiro governo eleito ${ }^{2}$ delibera em favor da edificação de uma cidade para ser a capital definitiva. Para tanto, fazia-se necessário selecionar o sítio, elaborar o seu projeto urbanístico e, não menos importante, liberar as terras deste sítio escolhido para a implantação do projeto urbano.

Para liberar essas terras, o governo (1989-1991) lança mão do poder expropriatório do Estado. ${ }^{3}$ Carlos (2011a, p. 64), ao considerar as noções de apropriação/produção/reprodução do espaço, aponta que é fundamental considerar os sujeitos, sendo o Estado o sujeito da "dominação política". Como tal, este governo estabelece os critérios para a desapropriação apoiado na declaração de utilidade pública, que concede poder unilateral, reiterando o domínio "[...] soberano do Estado de requisitar terras para si” (ROLNIK, 2015, p. 228) e implicando em táticas indenizatórias duvidosas. Paralelamente, em momentos específicos, o estado do Tocantins também lança mão de atos de desaposso arbitrários e abusivos, com a apoderação das terras implicadas, reiterando o predomínio do poder político. ${ }^{4}$

Tais ações provocam insatisfação nos atingidos, os "sujeitos sociais", que têm o seu espaço como condição para a "realização da vida" (CARLOS, 2011a, p. 64). Estes, primeiramente, buscam negociar com o estado do Tocantins, o expropriante, sem resultados efetivos. Por fim, buscam no poder judiciário a resolução para os problemas enfrentados com as desapropriações e os desapossamentos de suas terras.

Ressalta-se que o próprio estado do Tocantins dá início à especulação imobiliária, em Palmas, por meio do repasse das terras desapropriadas ou desapossadas, envolvendo outros

\footnotetext{
Rolnik (2015, p. 395), ante os projetos olímpicos do Rio de Janeiro, com as desapropriações de moradias e de terras, faz questão semelhante: "cidade de quem?" Sassen (2016, p. 99), considerando o "novo mercado global de terras", usa o termo "expulsões" para caracterizar o despojo de número crescente de agricultores e de moradores das cidades de suas terras, cabendo, portanto, os mesmos questionamentos. Marx (1991) aponta tema relevante nas cidades brasileiras, ao questionar: "Cidade no Brasil. Terra de quem?".

2 Foram realizadas, em 15 de novembro de 1988, pelo Tribunal Regional Eleitoral (TRE) de Goiás, eleições para o estado do Tocantins (para governador, vice-governador, senador e deputados federais e estaduais) que vigoraram até os pleitos regulares no país. Nestes pleitos, foram eleitos os governadores Siqueira Campos (1989-1991; 19951998; 1999-2002; 2011-2014), Moisés Avelino (1991-1994); Marcelo Miranda (2003-2009; 2015-2018), Carlos Henrique Gaguim (2009-2010), Sandoval Cardoso (2014) e Mauro Carlesse (2018).

3 No Brasil, as desapropriações são regidas pelo Decreto-Lei n³.365/41 (BRASIL, 1941), conhecido como "Lei Geral das Desapropriações".

4 Lefebvre (1978) aponta que o Estado exerce grande domínio sobre a sociedade. Isto parece notório, nas intervenções estatais sobre a propriedade privada, e claramente observável, nas ações de desapropriação e nos atos de despossessão de terras para a implantação de Palmas, no Tocantins.
} 
sujeitos, como os adquirentes, que, em parte, são "sujeitos sociais", mas também os sujeitos do "capital, com suas estratégias objetivando sua reprodução continuada [abrangendo] suas articulações com os demais setores da economia, como o mercado imobiliário" (CARLOS, 2011a, p. 64), para quem as terras se tornam reserva de valor. Como aponta a citada autora, "o processo de produção, sob o capitalismo, transforma o espaço em mercadoria, auferindolhe valor" (CARLOS, 2011b, p. 91).

Desse modo, cria-se um imbróglio que abarca esses sujeitos - sobretudo, o estado do Tocantins, que expropriou, e os atingidos, que foram expropriados - e cria-se um contexto de insegurança com relação à posse e à propriedade fundiária, desde o início da implantação dessa capital. Na concepção de Carlos (2011a, p. 52), trata-se de práticas socioespaciais, pois as ações e as reações desses sujeitos têm uma materialização espacial concreta, “[...] o que implica pensar na relação dialética sociedade/espaço", porque a sociedade se realiza no espaço e por meio do espaço, bem como nas mediações existentes nesta relação, resultando no contínuo "[...] movimento de apropriação/produção/reprodução do espaço em seus conteúdos sociais". ${ }^{5}$

Considerando-se, sobretudo, a apropriação ${ }^{6}$ das terras, há outras questões particulares, nas quais a dimensão espacial se torna premente, porque revela a prática socioespacial, a saber: de que maneira se deram as desapropriações e as despossessões ${ }^{7}$ de terras para a implantação dessa capital? Qual o papel do estado do Tocantins? Como reagiram os atingidos? Enfim, como, de fato, se desenrolou a liberação das terras rurais para a implantação do sítio urbano de Palmas?

Nesse contexto, e refletindo sobre o modo como a análise espacial contribui para o entendimento do real como produto de relações socioespaciais concretas, este artigo tem como objetivo compreender as desapropriações e as despossessões de terras para a implantação de Palmas, a capital projetada do estado do Tocantins, enfatizando os papéis dos governos estaduais e dos antigos moradores da área atingida. Para tanto, esta pesquisa se apoia em análises de caráter tanto social como espacial, contrapondo objetividades e contradições históricas e geograficamente determinadas, fundamentais ao exercício da reflexão da complexidade socioespacial. Por sua vez, sua operacionalização está apoiada

\footnotetext{
5 O debate sobre a apropriação/produção/reprodução do espaço é desenvolvido com base nas contribuições de Lefebvre ([1972] 1981), Harvey ([1973] 1980; 2005) e Carlos (2008; 2011a; 2011b), entre outros.

6 Para Lefebvre (1978, p. 164), a apropriação “[...] transforma a natureza - o corpo e a vida biológica, o tempo e o espaço dados - em bens humanos. A apropriação é a meta, o sentido e a finalidade da vida social” (tradução livre).

7 Trata-se de palavra de emprego/uso discreto na língua portuguesa, sendo utilizada, neste artigo, no sentido de esbulho da possessão, da posse, ou seja, despossessão, desaposso, que vem do verbo desapossar/esbulhar/despojar, que resulta em perda ou privação da posse, cabendo também os termos expropriação forçada, esbulho, despojo.
}

D

D Revista da Associação Nacional de Pós-graduação e Pesquisa em Geografia (Anpege).

D $D$

p.31-70, V.15, n.27, mai./ago. 2019. 
em pesquisas bibliográficas e documentais, bem como em pesquisas de campo, com a elaboração de tabelas e de mapeamentos.

\section{Desapropriações e despossessões de terras para a implantação da capital do estado do Tocantins}

Com o estabelecimento do estado do Tocantins, em 1989, entre as primeiras ações do governo eleito, em 1988, tem-se a tomada de decisão em favor da edificação de uma cidade para ser a capital definitiva, ou seja, decide-se pela criação de um sítio urbano. A Medida Provisória no 009, de $1^{\circ}$ de janeiro de 1989 (TOCANTINS, 1989a, p. 103), determina que a capital seja implantada na porção central do novo estado, porque contemplaria "todas as regiões com as mais equânimes distâncias e acesso às autoridades governamentais e aos benefícios do poder público". Nessa área, é estabelecido um quadrilátero de 90 x 90 quilômetros $\left(8.100 \mathrm{~km}^{2}\right)$ (Figura 1), estendido para $90 \times 120 \mathrm{~km}\left(10.800 \mathrm{Km}^{2}\right)$ (IPUP, 2002), que se torna área de utilidade pública passível de desapropriação para abrigar essa capital (TOCANTINS, 1989a).

A Lei no 009, de 23 de janeiro de 1989 (TOCANTINS, 1989b), reafirma a declaração de utilidade pública da área mencionada. Nesta área, a Assembleia Estadual Constituinte, por meio do Decreto Legislativo no 006, de 9 de fevereiro de 1989 (TOCANTINS, 1989c), delibera em favor das áreas Mangues e Canela, estabelecendo um novo quadrilátero de 32 x 32 quilômetros (com $1.024 \mathrm{~km}^{2}$ ), estendido para $32 \times 42 \mathrm{~km}\left(1.344 \mathrm{Km}^{2}\right)$ (IPUP, 2002), entre os municípios de Miracema do Tocantins, Tocantínia, Taquaruçu do Porto, Porto Nacional e Paraíso do Tocantins, e autoriza que o poder executivo estadual execute a desapropriação de terras para a implantação da capital na área Canela, entre a margem direita do rio Tocantins e a encosta arenítica de planalto residual denominada Serra do Lajeado, no município de Taquaruçu do Porto (Figura 1). ${ }^{8}$

Após essa demarcação, no projeto da capital (elaborado pelo GrupoQuatro Arquitetura, Planejamento e Consultoria Ltda., com sede em Goiânia), define-se uma “[...] 'área de urbanização', com 12 x 32 quilômetros (38.400 hectares)” (GRUPOQUATRO, 1989, p.1), que conta com uma área urbana macroparcelada, com 11.084,47 hectares, que, naquele momento, corresponde ao perímetro urbano, e duas áreas de expansão urbanas, uma ao

\footnotetext{
Ressalta-se que a criação dessa capital implicou na delimitação de um novo município, para o qual esta cidade seria o distrito-sede. Em $1^{\circ}$ de janeiro de 1988, foi fundado o município de Taquaruçu do Porto, em território desmembrado do município de Porto Nacional, tendo como distrito-sede Taquaruçu do Porto, até então, distrito de Porto Nacional (GOIÂS, 1988). Este novo município foi instalado em junho de 1989, mas, em 29 de dezembro de 1989, Taquaruçu do Porto cedeu sua condição de distrito-sede para Palmas, cujos limites municipais definitivos foram estabelecidos em fevereiro de 1990 (PALMAS, 1989; 1990).
} 
norte desta área macroparcelada, com 4.625 hectares, e outra ao sul, com 4.869 hectares (Figura 2), localizadas entre a rodovia TO-134 (atual TO-050/BR-010), a leste, e a avenida Parque, projetada no limite da cota de represamento do rio Tocantins para a construção da usina hidrelétrica (UHE) Luiz Eduardo Magalhães, a oeste, e entre os ribeirões Água Fria, ao norte, e Taquaruçu Grande, ao sul.

\section{Figura 1 - Tocantins: quadrilátero de $90 \times 90$ km, delimitado para sediar a capital estadual.}

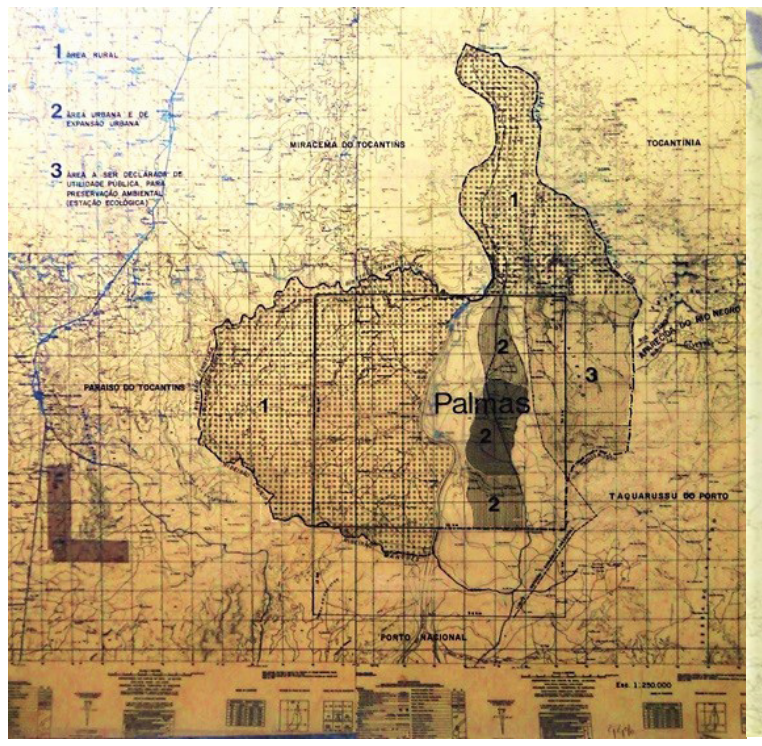

Fonte: Adaptado de IBGE, s.d.

\section{Figura 2 - Palmas: área urbana macroparcelada e áreas de expansão urbanas norte e sul do projeto da capital.}

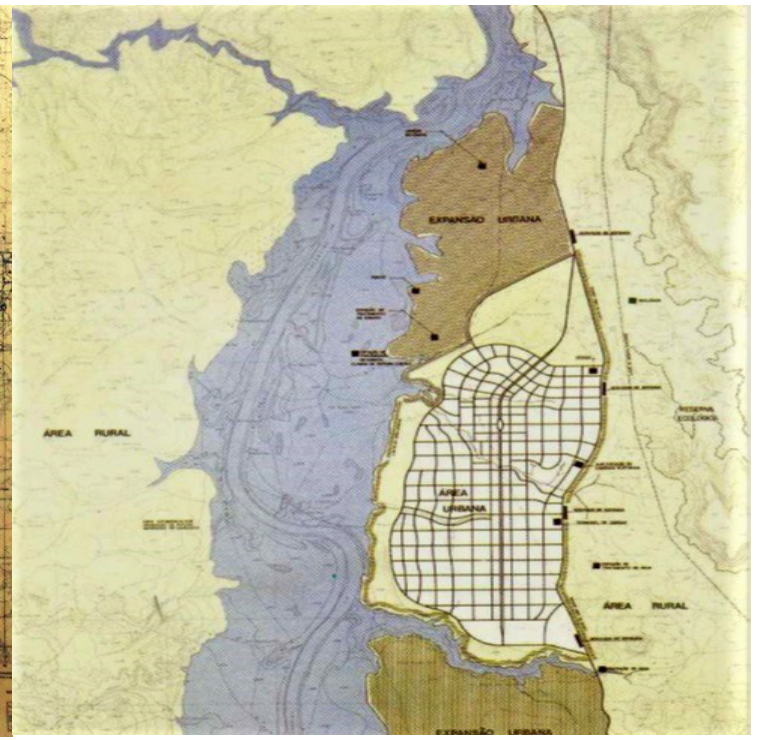

Fontes: GRUPOQUATRO (1989); Velasques (2010, p. 50).

Nessas terras sujeitas à desapropriação, encontrava-se um conjunto de propriedades e posses rurais, algumas em processo de regularização fundiária. Localizavam-se nessas terras, também, os povoados de Canela, na margem direita do rio Tocantins, e de Taquaralto, no entroncamento de rodovias (atuais TO-050/BR-010 e TO-030), até então, pertencentes ao município de Porto Nacional. Portanto, se tratava de um sítio já apropriado, e não de um sítio propriamente natural e completamente vazio de ocupação.

Do ponto de vista fundiário, as terras da porção centro-norte da área sujeita à desapropriação, que contém parte da área macroparcelada e a área de expansão urbana norte do projeto da capital (Figura 2), já tinham sido regularizadas, como exemplificam os loteamentos rurais Água Fria e Canela, cujos mapas de regularização datam de 1979 e 1981 (INCRA, 1979; 1981). Porém, as terras da porção centro-sul, que contém parte da área macroparcelada e a área de expansão urbana sul do projeto da capital (Figura 2), se encontravam em processo de regularização fundiária por meio da Ação Discriminatória 
no 335/82 (TOCANTINS, 1992). ${ }^{9}$ Tal ação foi implementada pelo Instituto Nacional de Colonização e Reforma Agrária (INCRA), em 17 de março de 1982, quando essa área ainda fazia parte do estado de Goiás, ${ }^{10}$ e envolvia três glebas de terras rurais: Canela, Taquaruçu e Taquari ou Tatá, em aproximadamente 28.500 hectares, composta de 160 propriedades e posses rurais, listados "os titulares de transcrições ou registros imobiliários no item 6 (fls 5/7) e os ocupantes no item 7 (fls. 7/8) da petição inicial” (TOCANTINS, 1992, p. 842).

\section{As desapropriações de terras para a construção de Palmas (1989 a 1991) e os primeiros atos de despossessão (1990 a 1991)}

Com essas definições, o primeiro governo estadual do Tocantins (1989-1991) inicia os procedimentos administrativos para o encaminhamento das desapropriações, cujas execuções se deram por via judicial, com o ajuizamento da ação judicial para efetivar a desapropriação. Em 13 de abril de 1989, são lançados dois decretos de desapropriação: o Decreto no 651/89 (TOCANTINS, 1989d), que, apesar de citar 17 propriedades rurais, atinge apenas 15 propriedades; e o Decreto no 655/89 (TOCANTINS, 1989e), que atinge 23 propriedades.

Em 27 de abril de 1989, são lançados outros três decretos de desapropriação: no Decreto n 665/89 (TOCANTINS, 1989f), são citadas nove propriedades rurais, porém, seis delas já haviam sido atingidas no Decreto $n^{\circ} 651$, restando apenas três propriedades abrangidas exclusivamente por esse decreto; no Decreto n 666/89 (TOCANTINS, 1989g), são citadas outras nove propriedades, mas duas delas foram atingidas no Decreto no 655 e duas têm a mesma matrícula citada em dois decretos diferentes, sendo, portanto, cinco propriedades abrangidas por esse decreto; e, no Decreto n 667/89 (TOCANTINS, 1989h), citam-se propriedades já enumeradas no Decreto nº 651/89.

De maio de 1989 a janeiro de 1990, outras 57 propriedades rurais foram atingidas pelas desapropriações, porém, suas ações judiciais foram encaminhadas por meio do Decreto Legislativo no 006 (TOCANTINS, 1989c). Em fevereiro de 1991, antes do fim desse primeiro mandato, o então governador amplia a área de desapropriação, atingindo outras 17 propriedades rurais, também por meio do Decreto Legislativo no 006 (TOCANTINS,

\footnotetext{
É importante observar que, "uma vez instaurado o processo discriminatório administrativo, o oficial do registro de imóveis não efetuará matrícula, registro, inscrição ou averbação estranhas à discriminação, relativamente aos imóveis situados, total ou parcialmente, dentro da área discriminada" (BRASIL, 1976, p. 3).

10 Em 1990, a Ação Discriminatória n 335/82 (TOCANTINS, 1992) se torna responsabilidade do poder judiciário do estado do Tocantins, sob o número 057/90 (TOCANTINS, 1992).
} 
1989c). De acordo com dados da Associação de Proprietários e Posseiros da Área Destinada à Construção da Capital do Tocantins (APPACCTO, 2016), há outras quatro propriedades e 16 posses rurais atingidas pelas desapropriações vinculadas ao Decreto Legislativo $\mathrm{n}^{\circ}$ 006 (Tabela 1; Figura 3), das quais há apenas dados sobre a localização dos imóveis e a identidade dos proprietários ou dos posseiros, não havendo registros das ações judiciais de desapropriação.

No sítio escolhido para sediar a capital do estado do Tocantins, até março de 1991, ainda no primeiro governo estadual (1989-1991), foram atingidas pelas desapropriações 140 propriedades e posses rurais (Tabela 1; Figura 3), sendo 46 propriedades (32,9\% do total) por meio de decretos do poder executivo estadual, e 94 propriedades e posses $(67,1 \%$ do total) por meio do Decreto Legislativo no 006 (TOCANTINS, 1989c). Fica evidente que o principal instrumento para essas desapropriações foi o referido decreto legislativo, utilizado, sobretudo, para abranger as terras citadas na Ação Discriminatória no 335/82 (TOCANTINS, 1992). ${ }^{11}$ Os decretos de desapropriação do poder executivo estadual não abrangeram os imóveis citados nesta ação discriminatória, mas, sim, os loteamentos rurais Água Fria e Canela, já regularizados pelo INCRA (1979; 1981).

A área abrangida nas desapropriações atingiu, computando a área obtida no levantamento de dados, mais de 44.300,04 hectares (Tabela 1). Para a APPACCTO (1990), cerca de 45.000 hectares foram atingidos. Ainda que este seja um dado parcial, comprova que se trata de área muito mais ampla que a do perímetro urbano (11.084,47 hectares) mesmo somadas as áreas de expansão urbanas norte (4.625 hectares) e sul (4.869 hectares), totalizando 20.578,47 hectares - e que a área de urbanização (38.400 hectares) previstas no projeto da capital (GRUPOQUATRO, 1989).

Vale observar que, quando da aprovação da Lei no 009 (TOCANTINS, 1989b, p. 2223), a declaração de utilidade pública (que possibilita a desapropriação) tem como finalidade "[...] abrigar a capital definitiva do estado do Tocantins", ressaltando a competência do chefe do poder executivo estadual para “[...] desapropriar as áreas para sediar a capital definitiva, inclusive aquelas destinadas à expansão urbana”. Este entendimento é reafirmado no Decreto Legislativo no 006 (TOCANTINS, 1989c, p. 122), ao estabelecer que o poder executivo estadual está "[...] autorizado a promover a desapropriação, na área denominada "Canela", da área necessária à implantação da sede definitiva". Atentando a estas finalidades, as desapropriações deveriam se ater à área de implantação de Palmas, basicamente, perímetro urbano e áreas de expansão urbanas.

\footnotetext{
${ }^{11}$ Ressalta-se que apenas 39 das 160 propriedades e posses rurais citadas na Ação Discriminatória n $335 / 82$ (TOCANTINS, 1992) foram envolvidas nas ações de desapropriações de 1989 a 1991.
}

D D Revista da Associação Nacional de Pós-graduação e Pesquisa em Geografia (Anpege).

D D p.31-70, V.15, n.27, mai./ago. 2019 
Tabela 1 - Palmas: propriedades e posses rurais atingidas nas desapropriações do governo estadual do Tocantins de abril de 1989 a março de 1991.

\begin{tabular}{|c|c|c|c|}
\hline Decretos & \multicolumn{2}{|c|}{ Propriedades e posses atingidas } & $\begin{array}{c}\text { Área aproximada atingida } \\
\text { em hectares }{ }^{3}\end{array}$ \\
\hline Decreto n. $651 / 89$ & 15 & $10,7 \%$ & $3.779,26$ \\
\hline Decreto n. 655/89 & 23 & $16,5 \%$ & $8.987,02$ \\
\hline Decreto n. 665/89 & 3 & $2,1 \%$ & $1.229,36$ \\
\hline Decreto n. 666/89 & 5 & $3,6 \%$ & $2.291,70$ \\
\hline Decreto n. $667 / 89^{1}$ & -- & -- & -- \\
\hline Decreto n. 006/89 & $94^{2}$ & $67,1 \%$ & $28.012,70$ \\
\hline Total & 140 & $100 \%$ & $44.300,04^{3}$ \\
\hline
\end{tabular}

Fontes: TOCANTINS (1989d; 1989e; 1889f; 1989g; 1989h; 1989c); TERRAPALMAS (2015); APPACCTO (2016). ${ }^{1}$ Citou propriedades já enumeradas no Decreto $651 / 89 .{ }^{2}$ São 78 propriedades e 16 posses rurais. ${ }^{3}$ Não foi obtido o dado da área de todas as propriedades atingidas, portanto, o dado da área total é parcial. 
Figura 3 - Palmas: áreas atingidas nas desapropriações do governo estadual do Tocantins de abril de 1989 a março de 1991.

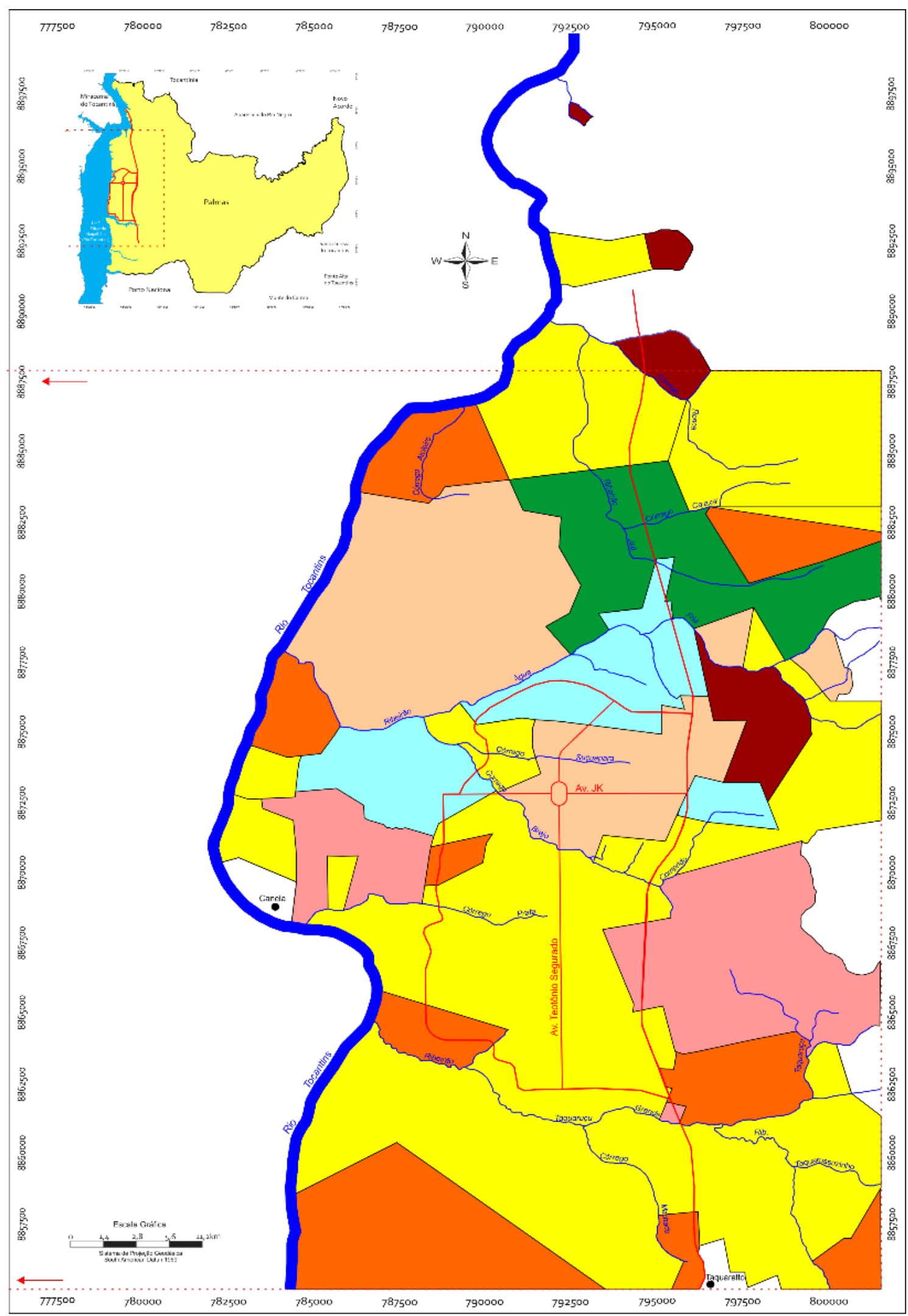

\section{LEGENDA:}
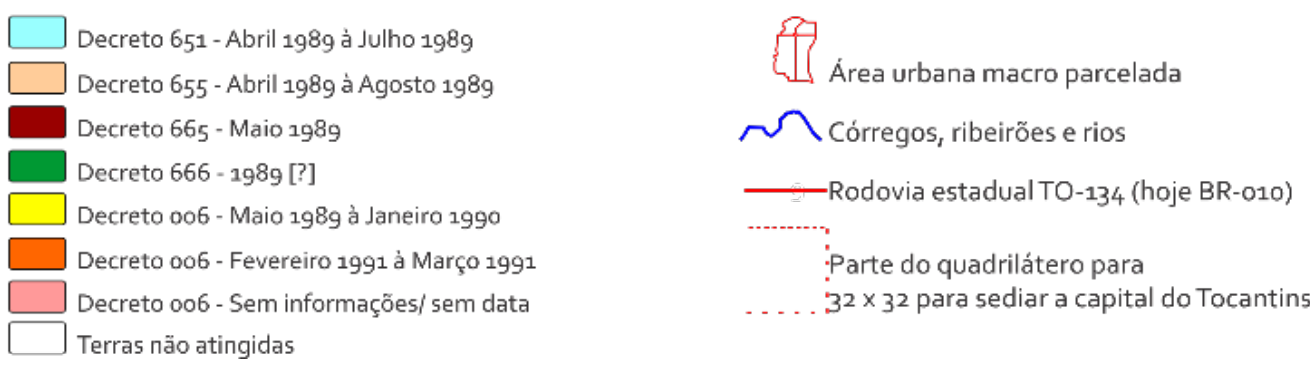

Fontes: TOCANTINS (1989d; 1989e; 1889f; 1989g; 1989c); TERRAPALMAS (2015); APPACCTO (2016).

D D D Revista da Associação Nacional de Pós-graduação e Pesquisa em Geografia (Anpege).
D

p.36-66, V.15, n.27, mai./ago. 2019. 
Os dados parciais levantados evidenciam, porém, que as desapropriações atingiram área superior do que a informada, implicando em desvios de finalidade e causando descontentamento entre os atingidos, juntamente com o cálculo das indenizações, que utiliza como referência a avaliação do Instituto de Avaliação Municipal (IAM) de Porto Nacional, empregada para estabelecer o valor dos impostos a serem cobrados do proprietário da terra, e que, nesse período, correspondia a 320,00 Cruzados Novos por alqueire, com pequenas variações entre uma e outra propriedade (GOVERNADOR..., 1989; TOCANTINS, 1989i; 19891; 1989m; 1990; 1991; APPACCTO, 1990). Assim, os valores das indenizações também causaram insatisfação entre os atingidos, agravada pela desconsideração das benfeitorias presentes nas propriedades desapropriadas, sobretudo nas ações judiciais encaminhadas por meio do Decreto Legislativo nº 006/89 (TOCANTINS, 1989c).

No encaminhamento judicial para a execução das desapropriações, o então governo estadual (1989-1991) alega urgência e solicita a imissão de posse provisória, como previsto no Decreto-Lei no 3.365/41 (BRASIL, 1941). Com o depósito prévio do valor das indenizações em conta bancária do expropriado, tem-se a autorização judicial de imissão de posse provisória em favor do expropriante, e, em setembro de 1989, se iniciam os despejos na área. Estes despejos contaram com aparato policial, que adentrou os imóveis em desapropriação e destruiu casas e benfeitorias, ampliando as insatisfações dos atingidos (GOVERNADOR..., 1989).

Ademais, esse governo passa a negociar as terras envolvidas nas desapropriações, mormente, na forma de lotes urbanos e de chácaras no entorno do perímetro urbano projetado, iniciando a especulação imobiliária, em Palmas, com terras enredadas em ações judiciais de desapropriação, por meio de editais de licitações e de leilões públicos, de venda direta e em regime de comodato, de dação em pagamento e de doações, porque, uma vez obtida a imissão provisória de posse, tem-se o entendimento de que o apossamento é irreversível.

Esse apossamento das terras se torna explícito no momento em que se lança, pela Secretaria de Estado da Viação e Obras Públicas, o Edital de Concorrência Pública nº 026, de 28 de novembro de 1989 (TOCANTINS, 1989n, p. 46), para a alienação de imóveis no denominado "loteamento Palmas [...] local destinado à implantação da futura capital". O Cartório de Registro de Imóveis, à época, noticia “[...] que pelo Governo do Estado, por seu representante legal, depositou, neste Cartório, o projeto e demais documentos relativos ao imóvel de sua propriedade, situado na área de expansão urbana desta cidade, no lugar

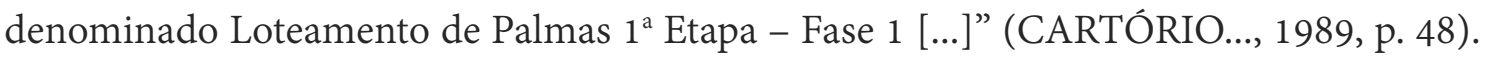
Uma das controvérsias sobre a desapropriação dessas terras diz respeito à transferência 
de terras expropriadas do ente público para entes privados, principalmente com ganhos imobiliários, via valorização e especulação, em prejuízo dos expropriados. Este tipo de apossamento com repasse ao setor privado é, para Harvey (2004, p. 133), “[...] um processo de despossessão bárbara.”

Diante desse contexto de insatisfação com os valores das indenizações e de dissenso com o procedimento expropriatório no que diz respeito à finalidade pública alegada, somado à proposta de formação de um "cinturão verde", no entorno da capital, para abastecimento de hortifrutigranjeiros, a partir da cessão das terras desapropriadas a outros produtores agrícolas, os proprietários e os posseiros atingidos criam, em 11 de maio de 1989, a Associação de Proprietários e Posseiros da Área Destinada à Construção da Capital do Tocantins (APPACCTO). A criação desta associação não representa oposição à construção da capital, mas, sim, um movimento em busca de melhores condições de negociação em face das desapropriações. A APPACCTO tenta argumentar com o governo estadual, requerendo, sobretudo, a suspensão dos despejos e os reparos pelos danos causados, a revisão das avaliações e a indenização pelas benfeitorias, a atualização monetária do valor pago nas indenizações, a possibilidade de permuta entre as terras rurais e as terras urbanas e a revisão da questão das áreas de posse, entre outras reivindicações, incluindo o desejo de alguns de permanecerem nas terras destinadas à formação do "cinturão verde", já que eram agricultores e criadores que viviam nestas terras, com vínculos regionais (APPACCTO, 1989b; 1989c).

Não houve, por parte do governo estadual de então, um abrandamento de sua postura em relação aos atingidos, e as negociações não alcançaram resultados positivos. Perante os impasses, a APPACCTO buscou sensibilizar a população e a mídia com um manifesto escrito em que se lê: "Palmas: capital da injustiça, aventura imobiliária e ilegal de um estado pobre, que planeja construi-la às custas do patrimônio, arrancado à força bruta, dos desapropriados", e, com relação às indenizações, se lê: "O governo depositou em juízo a quantia ridícula de TREZENTOS E VINTE CRUZADOS NOVOS por alqueire desapropriado [...]. Agora, revende as terras em lotes urbanos por mais de DEZ MILHÕES DE CRUZEIROS [...] cada alqueire desapropriado [...]." (APPACCTO, 1990, s. p.). Este manifesto remete aos apontamentos de Harvey (2004, p. 118) sobre tais ações do Estado como “[...] processos muitas vezes violentos de espoliação", com “[...] acumulação via espoliação dos ativos dos mais pobres". Houve também, por parte da APPACCTO, tentativas de sensibilização dos parlamentares da Assembleia Estadual Constituinte, dos políticos eleitos para os cargos municipais (prefeito e vereadores) e do procurador geral da República, no sentido de se mostrar as ações arbitrárias, coercitivas e, até mesmo, violentas desse governo estadual e os problemas enfrentados pelos atingidos.

D

D D Revista da Associação Nacional de Pós-graduação e Pesquisa em Geografia (Anpege).

D D p.31-70, V.15, n.27, mai./ago. 2019. 
Nesse contexto, as ações judiciais de desapropriação avançavam lentamente, pelas dificuldades de negociação entre o expropriante e os expropriados. O então governo estadual, de outubro de 1990 a março de 1991, solicita, administrativamente, a abertura de seis novas matrículas no Cartório de Registro de Imóveis (CRI) de Palmas, por meio de uma ação de legalidade questionável, porque foi a cabo sem o devido processo legal (ADVOCACIA..., 1991a; 1991b). Tais matrículas correspondem às glebas rurais Água Fria (matrícula nº 2.756) e Canela (matrícula nº 2.749), já regularizadas pelo INCRA (1979; 1981), e Canela (matrícula no 2.759), Taquaruçu (matrícula n².761), Taquari ou Tatá (matrícula $n^{\circ}$ 2.735) e Santa Fé (matrícula no 2.760) (Figura 4), que correspondem às terras citadas na Ação Discriminatória no 335/82 (TOCANTINS, 1992) e estão, portanto, em processo de regularização fundiária desde 1982. Ademais, a maior parte dessa área estava citada nas ações judiciais de desapropriação, sendo concedido ao expropriante apenas o direito de posse, por conta da imissão provisória, que não implica o registro de novas matrículas.

Em abril de 1991, já no segundo governo estadual (1991-1994), o CRI de Palmas envia um ofício ao CRI de Porto Nacional solicitando o cancelamento das matrículas citadas nos ofícios do primeiro governo estadual (1989-1991), pois estes imóveis estavam registrados no Cartório de Porto Nacional, para que se concretizasse o registro das seis matrículas em favor do estado do Tocantins (Figura 4), à revelia das ações judiciais de desapropriação. Com esses atos, verificam-se, concomitantemente, o despojo e a apoderação dessas terras. Trata-se, portanto, de atos de despossessão abusivos e paralelos às ações judiciais de desapropriação, configurando abuso de poder e conivência dos entes envolvidos. Nas palavras de Harvey (2004, p. 121), trata-se de "práticas predatórias", muitas vezes, por desapossamento, em que "o Estado, com seu monopólio de violência e suas definições de legalidade, tem papel crucial no apoio e na promoção desses processos.”

Em Palmas, a extensão da área desapossada, nesses atos, supera consideravelmente as áreas de perímetro e de expansões urbanas do projeto da capital, bem como as áreas envolvidas nas ações judiciais de desapropriação impetradas de 1989 a 1991 (Figura 3; Figura 4). 
Figura 4 - Palmas: matrículas registradas em favor do estado do Tocantins, de outubro de 1989 a março de 1991.

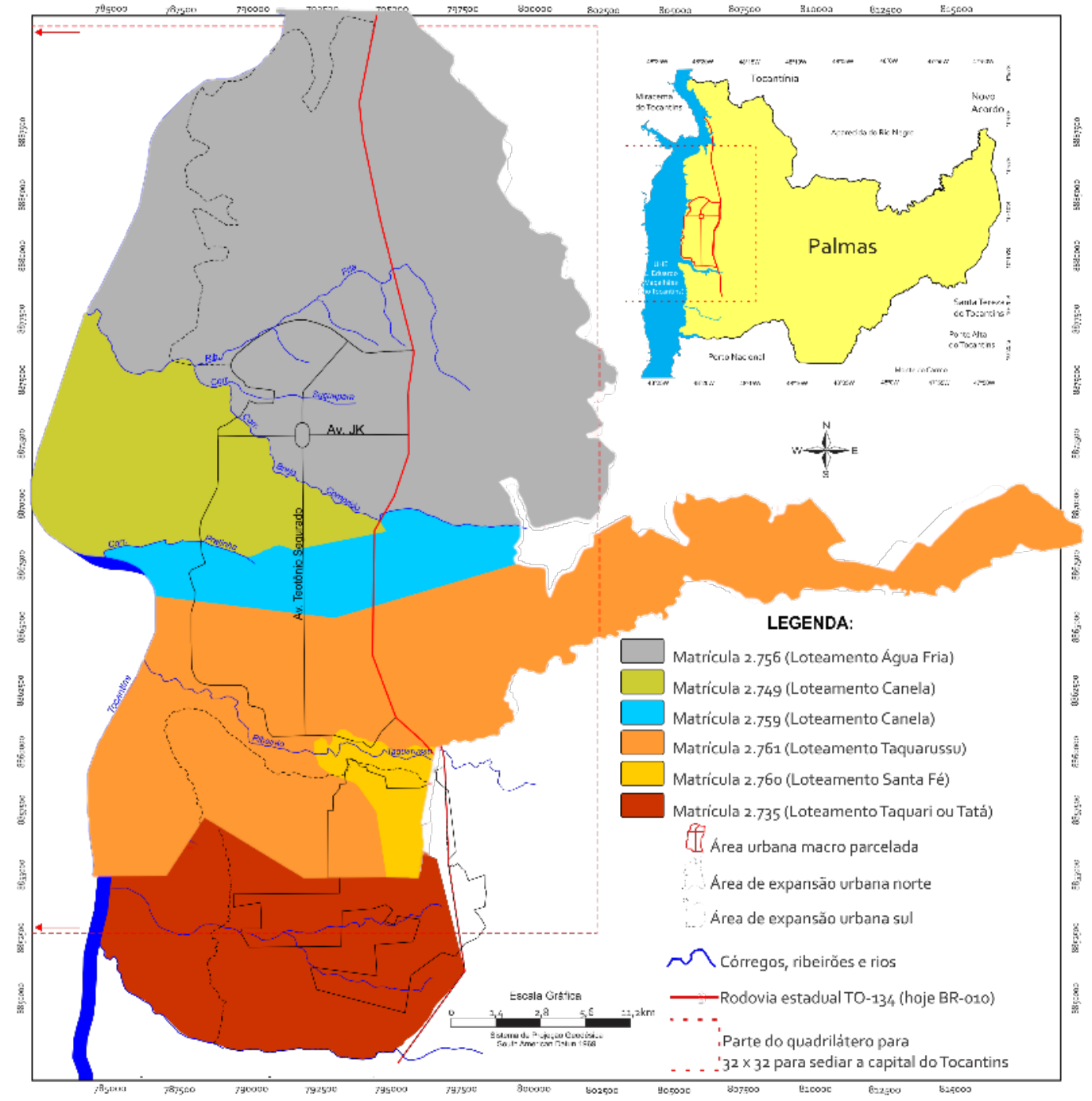

Fontes: ADVOCACIA... (1991a; 1991b); CARTÓRIO... (1991); APPACCTO (2016).

De abril de 1989 a março de 1991, quando se finda o primeiro mandato do governador eleito em 1988, havia apenas 14 propriedades rurais (10\% do total) com as ações judiciais sentenciadas, sendo 12 desapropriadas e duas devolvidas aos atingidos, porque o expropriante desistiu da desapropriação. As terras restantes (90\% do total) ainda estavam envolvidas nas ações judiciais de desapropriação. No caso das propriedades rurais efetivamente desapropriadas, nesse momento, observa-se que alguns expropriados aceitaram a oferta do expropriante, recebendo apenas o valor da indenização proposto, enquanto outros

D

D

D D Revista da Associação Nacional de Pós-graduação e Pesquisa em Geografia (Anpege).

D D

p.31-70, V.15, n.27, mai./ago. 2019. 
pediram a revisão da indenização proposta, e, além desta, receberam imóveis em dação em pagamento indenizatório - incoerentemente, situados na própria área desapropriada. Somente nesses casos de desapropriação com sentenças finalizadas, haveria a transferência das titularidades das terras do expropriado para o expropriante, com registro em cartório, conforme o Decreto-Lei no 3.365/41 (BRASIL, 1941).

Com as novas matrículas, o governo do estado do Tocantins amplia as alienações, dações e doações de terras com envolvimento dos adquirentes, inclusive, com emissão de títulos, sobretudo via Companhia de Desenvolvimento do Estado do Tocantins (CODETINS), no caso dos lotes urbanos, e via Instituto de Terras do Estado do Tocantins (ITERTINS), no caso das chácaras no entorno do perímetro urbano projetado. Ressalta-se que alguns atingidos não permitiram a ocupação e, imediatamente, acionaram o poder judiciário para garantir que suas terras não fossem ocupadas pelos adquirentes das alienações estaduais e para aguardar a sentença das ações judiciais de desapropriação e discriminatória. Tal fato induz o ITERTINS a cancelar 39 matrículas, em dezembro de 1991, e outras 18 matrículas, em fevereiro de 1992, todas expedidas pelo CRI de Palmas, alegando que os imóveis foram alienados sem cumprir os preceitos legais, que se encontravam sub-judice na citada ação discriminatória, não havendo permissão legal para a mudança da transcrição imobiliária, “[...] considerando que só ao legítimo ocupante é assegurado o direito de regularização fundiária”, e que "a referida área não foi regularmente incorporada ao patrimônio público estadual" (ITERTINS, 1991a, p. 14; 1991b, p. 15).

As desapropriações e os atos abusivos no cancelamento das matrículas dos atingidos, no CRI de Porto Nacional, e no registro das seis novas matrículas, no CRI de Palmas, bem como o cancelamento das matrículas dos adquirentes nas alienações do próprio Estado geram insegurança fundiária e ampliam os conflitos. Os atingidos buscam, no poder judiciário, a resolução dos impasses gerados, e, desse modo, os interesses do Estado se depararam com as resistências daqueles que viviam no lugar, para quem essas terras eram terras de uso, de trabalho, de realização da vida, e para quem as indenizações deveriam garantir, apesar das mudanças significativas nos seus hábitos, a continuidade de seu modo vida.

\section{As devoluções de parte das terras atingidas (1991-1994) e as irresoluções perante os atos de despossessões (1990-1991)}

O segundo governador eleito (1991-1994), diante dos conflitos e do cenário de insegurança fundiária, adotou postura conciliatória, no sentido de garantir encaminhamentos para as desapropriações e para a própria construção de Palmas. Assim, se comprometeu 
a devolver parte das terras atingidas, sobretudo as que se encontravam fora do perímetro urbano e das áreas de expansão urbanas do projeto da capital, e também se empenhou na busca de acordos mais satisfatórios para as áreas que seriam efetivamente desapropriadas.

Em fins de 1994, parte importante das ações judiciais de desapropriação é julgada. Das 15 propriedades rurais atingidas pelo Decreto no 651/89 (TOCANTINS, 1989d), nove foram desapropriadas, uma teve parte desapropriada e parte devolvida ao atingido, duas foram devolvidas aos atingidos e sobre três delas não se obtiveram informações. Das 23 propriedades rurais atingidas pelo Decreto no 655/89 (TOCANTINS, 1989e), dez foram desapropriadas, três foram devolvidas aos atingidos e sobre dez delas não se obtiveram informações. As três propriedades rurais atingidas pelo Decreto nº 665/89 foram devolvidas aos atingidos (TOCANTINS, 1989f). As cinco propriedades rurais abrangidas pelo Decreto $n^{\circ}$ 666/89 (TOCANTINS, 1989g) foram desapropriadas. Das 94 propriedades e posses rurais atingidas pelo Decreto Legislativo no 006/89 (TOCANTINS, 1989c), 11 foram desapropriadas, duas tiveram parte desapropriada e parte devolvida ao atingido, 40 foram devolvidas aos atingidos e sobre 41 não se obtiveram informações (Tabela 2; Figura 5).

Assim, totalizam 86 propriedades $(61,4 \%)$ com sentenças finalizadas nas ações judiciais de desapropriação, sendo que $25 \%$ foram desapropriadas, $2,1 \%$ foram parte desapropriada e parte devolvida aos atingidos, e 34,3\% foram devolvidas aos atingidos. Porém, sobre $38,6 \%$ destas propriedades e posses rurais não se obtiveram informações acerca de sua situação, nesse período (Tabela 2). Em 1995, foram sentenciadas outras duas propriedades, sendo uma desapropriada e outra devolvida ao atingido, e, em 1997, outra propriedade foi desapropriada. Até 1997, havia 89 propriedades rurais (63,6\% do total) com sentenças finalizadas nas ações judiciais de desapropriação (Figura 5).

$\mathrm{Na}$ tramitação das ações judiciais de desapropriação em que as terras foram desapropriadas nesse período, alguns dos expropriados aceitaram, além do valor depositado em conta bancária quando da imissão provisória de posse, o acordo inicial proposto, mesmo que os valores não levassem em conta as benfeitorias e não fossem percebidos como justos. Outros expropriados firmaram acordos mais vantajosos, inclusive por meio do repasse de glebas de terras, urbanas e rurais, além da indenização inicial proposta. Neste caso, o segundo governo estadual (1991-1994) utilizou o mecanismo dação de terras em pagamento indenizatório. Na tramitação das ações judiciais de desapropriação em que as terras foram devolvidas aos atingidos, a maioria destas se deu pela ausência do decreto de desapropriação do poder executivo e pelo uso do Decreto Legislativo nº 006/89 (TOCANTINS, 1989c), que anula a ação já em sua proposição. Como exemplo disto, citam-

D

D D Revista da Associação Nacional de Pós-graduação e Pesquisa em Geografia (Anpege).

D D

p.31-70, V.15, n.27, mai./ago. 2019. 
se os autos de desapropriação por utilidade pública de número 2.099/89 (TOCANTINS, 1989j), em que se lê:

Determina o art. 13, do Dec.-Lei n.3.35/41, que a inicial da ação de desapropriação por utilidade pública, como neste caso, será instruída com o ato expropriatório. Essa prova não existe nestes autos e intimado a fazê-la, o Expropriante não atendeu a ordem judicial. Por isso, INDEFIRO a petição inicial desta ação e, de consequência, DECLARO EXTINTO o processo, sem julgamento de mérito, determinando seu ARQUIVAMENTO, após as formalidades legais [...]. (TOCANTINS, 1989j, p. 90).

Tabela 2 - Palmas: situação das propriedades e posses rurais atingidas nas desapropriações do governo estadual do Tocantins de 1989 a 1994.

\begin{tabular}{|c|c|c|c|c|c|c|c|c|}
\hline \multirow[t]{2}{*}{ Decretos } & \multicolumn{2}{|c|}{$\begin{array}{l}\frac{\pi}{0} \\
\frac{0}{2} \\
\frac{0}{2} \\
\frac{0}{0} \\
\frac{0}{0}\end{array}$} & \multicolumn{2}{|c|}{ 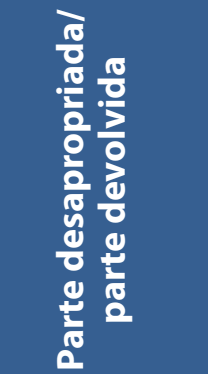 } & \multicolumn{2}{|c|}{$\frac{0}{0}$} & \multicolumn{2}{|c|}{ 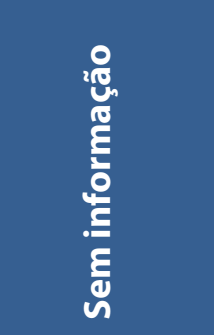 } \\
\hline & 9 & $6,4 \%$ & 1 & $0,7 \%$ & 2 & $1,4 \%$ & 3 & $2,1 \%$ \\
\hline Decreto n 655/89 & 10 & $7,2 \%$ & -- & -- & 3 & $2,1 \%$ & 10 & $7,2 \%$ \\
\hline Decreto n 665/89 & -- & -- & -- & -- & 3 & $2,1 \%$ & -- & -- \\
\hline Decreto n 666/89 & 5 & $3,5 \%$ & -- & -- & -- & -- & -- & -- \\
\hline Decreto nº 006/89 & 11 & $7,9 \%$ & 2 & $1,4 \%$ & 40 & $28,7 \%$ & 41 & $29,3 \%$ \\
\hline Total' & 35 & $25 \%$ & 3 & $2,1 \%$ & 48 & $34,3 \%$ & 54 & $38,6 \%$ \\
\hline
\end{tabular}

Fontes: TOCANTINS (1989d; 1989e; 1989f; 1989g; 1989c; 1989i, 1989l; 1989m; 1990;1991); TERRAPALMAS (2015); APPACCTO (2016). ${ }^{1}$ Com aproximações decimais. 
Figura 5 - Palmas: situação das áreas atingidas nas desapropriações do governo estadual do Tocantins de 1989 a 1997.

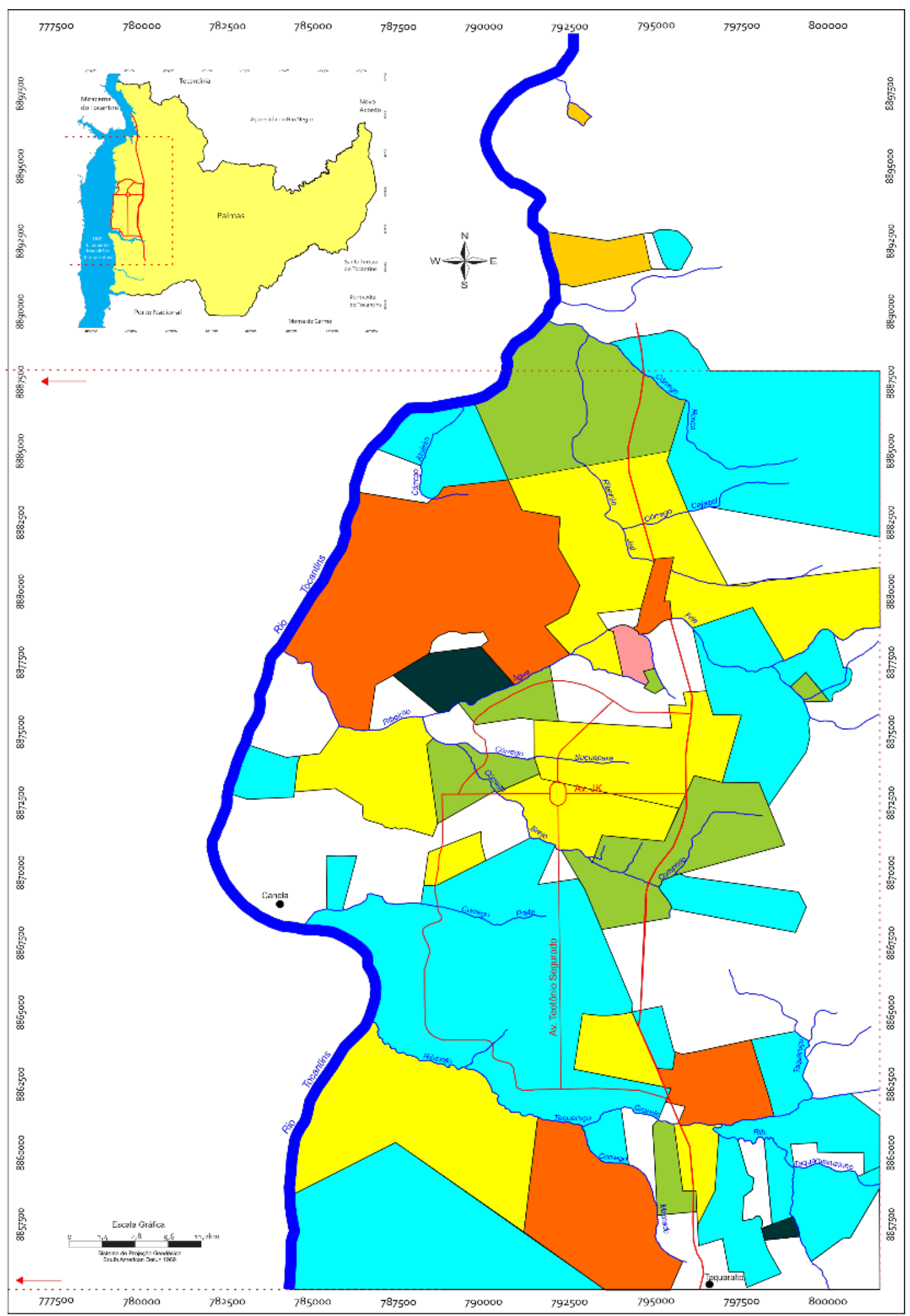

\section{LEGENDA:}

$\square$ Terras desapropriadas - Abril 1989 à Março 1991

$\square$ Terras devolvidas - Abril 1989 à Março 1991

$\square$ Terras desapropriadas - Março 1991 à 1994

$\square$ Terras devolvidas - Março 1991 à 1994

Terras parte desapropriada/parte devolvida - Março 1991 à 1994

Terras desapropriadas - 1995

Terras devolvidas - 1995

Terras desapropriadas - 1997

Fontes: TOCANTINS (1989d; 1989e; 1989f; 1989g; 1989c; 1989i; 1989l; 1989m; 1990;1991); TERRAPALMAS (2015); APPACCTO (2016).

D D Revista da Associação Nacional de Pós-graduação e Pesquisa em Geografia (Anpege).
D

p.36-66, V.15, n.27, mai./ago. 2019. 
De forma contraditória, ressalta-se que algumas propriedades rurais foram desapropriadas com base no Decreto Legislativo no 006/89 (TOCANTINS, 1989c) (Tabela 2; Figura 5), em função da interpretação ajuizada na sentença. Outras situações em que as terras foram devolvidas aos atingidos se deram pela desistência do expropriante, o que leva à perda de finalidade da referida ação judicial, que, por sua vez, é extinta, e o bem é devolvido.

Com as sentenças dessas ações judiciais de desapropriação, para os atingidos e para o poder judiciário, os problemas estavam resolvidos. Contudo, permanecem pendências, sobretudo no que diz respeito às negociações realizadas pelo estado do Tocantins com parte dessas terras que envolvem terceiros que as adquirem a partir de 1989, com títulos emitidos pelo próprio Estado, pelo Codetins ou pelo Itertins e registrados no CRI de Palmas. Mas, sem dúvida alguma, a principal pendência foi a cartorial, porque, com as sentenças emitidas e a finalização das ações de desapropriação, não foram tomados os devidos cuidados com os registros cartoriais, fosse com a efetiva desapropriação, fosse com a devolução das terras aos atingidos. No CRI de Porto Nacional, permaneceu o cancelamento das matrículas citadas nos ofícios do primeiro governo estadual (1989-1991), e, no CRI de Palmas, permaneceu o registro das seis matrículas criadas em favor do estado do Tocantins, por ato administrativo, bem como a maioria dos registros das alienações realizadas pelos governos estaduais ou com o seu aval.

Mesmo com a extinção da maioria das ações judiciais de desapropriação que estavam associadas ao Decreto Legislativo no 006 (TOCANTINS, 1989c), com a devolução das terras aos atingidos, o interesse do estado do Tocantins nestas terras permaneceu, porque parte destas estava na área de macroparcelamento e nas áreas de expansão urbanas do projeto da capital. Por conta disso, novas desapropriações são encaminhadas, com base no citado decreto legislativo, mesmo diante da impossibilidade já posta pelo poder judiciário. Estas, porém, são executadas por meio de procedimento administrativo, via Procuradoria Geral do Estado do Tocantins, o que permitia maior agilidade e acordos diretos, sem a mediação do judiciário. Assim, são lançados os denominados processos administrativos de números 1.552, 1.553, 1.561, 1.562 e 1.569, em 1992, que atingem sete propriedades rurais, e de número 39, em 1993, que atinge uma propriedade rural (TOCANTINS, 1996). Os acordos firmados, de agosto de 1993 a novembro de 1994, entre o expropriante e os expropriados, tratam de indenizações em dinheiro e em imóveis, por meio da dação em pagamento indenizatória (TOCANTINS, 1996), como já havia sido feito em acordos das ações desapropriatórias executadas por via judicial. 
As desapropriações vinculadas a esses procedimentos administrativos são consideradas amigáveis. Todavia, faz-se necessário ressaltar que, com o cancelamento das matrículas no CRI de Porto Nacional e a consequente criação das seis matrículas no CRI de Palmas, nos atos despossessórios, essas terras estavam registradas em nome do estado do Tocantins. Isto leva a crer que as citadas desapropriações não foram assim tão amigáveis, tendo em vista que os atingidos não detinham, de fato, a titulação de suas terras. Ademais, parece bastante incoerente que o expropriante lance procedimentos administrativos de desapropriação para terras cujos registros imobiliários estão em nome do próprio expropriante. Na prática, o governo estadual (1991-1994) desapropriou essas terras por meio de suas antigas matrículas, como registrado nas escrituras públicas de desapropriação amigável, dação em pagamento indenizatória e outras avenças (TOCANTINS, 1996). Prevalecem, portanto, as práticas de cooptação e de conivência dos entes envolvidos no "mistério da titulação", para usar a expressão de Rolnik (2015), bem como de coerção, no que diz respeito aos atingidos, e de apropriação, no que diz respeito às terras, porque o poder judiciário já tinha arbitrado como inválido o uso do citado decreto legislativo para amparar atos contra a propriedade privada.

\section{As sentenças da Ação Discriminatória n $335 / 82$ (1992) e da Apelação Cível n 1.620/95 (1997/1999) e o novo ato de despossessão de terras (1999)}

A sentença da Ação Discriminatória no 335/82 (TOCANTINS, 1992, p. 848), emitida em 4 de maio de 1992, reconhece as irregularidades fundiárias na área dos imóveis rurais denominados Canela, Taquaruçu e Taquari ou Tatá, posto que "[...] toda a documentação originária existente, verdadeira ou falsa, legítima ou nula, trata de negócios jurídicos referentes à "posse de terras", e não à propriedade”, porque as “[...] transcrições imobiliárias, nela existentes, foram levadas a feito indevidamente, pois fundadas em formais de partilha referentes a simples posse (hoje metamorfoseadas em propriedades) e que, por isto, as ditas terras jamais se desincorporaram do patrimônio público" (TOCANTINS, 1992, p. 853). Desse modo, a referida sentença aponta que se trata de terras devolutas da União - de fato, do estado do Tocantins, após sua criação -, e encaminha os procedimentos no sentido da regularização fundiária, determinando o cancelamento dos registros inscritos indevidamente, para que se regularize a situação da propriedade, mediante títulos que deveriam ser emitidos pelo estado do Tocantins (o ente público) e devidamente inscritos em cartório, como determina a Lei de Terras (BRASIL, 1850). Mas, precedentemente a isso, reconhece que há um direito possessório dos ocupantes.

D

D D Revista da Associação Nacional de Pós-graduação e Pesquisa em Geografia (Anpege).

D D

p.31-70, V.15, n.27, mai./ago. 2019. 
Tendo em vista que uma das finalidades da ação discriminatória é a de propiciar a regularização da posse, como bem acentuou o autor às fls. 730, fica, portanto, resguardado esse direito aos posseiros existentes na área objeto da lide e que a ele fizer jus (TOCANTINS, 1992, p. 854).

DO EXPOSTO, e levando em consideração tudo o mais que dos autos consta, JULGO PROCEDENTE a presente ação discriminatória e, de consequência, DECLARO pertencer ao domínio público estadual, ou seja, ao ESTADO DO TOCANTINS a área aproximada de 28.500 hectares, situada nos imóveis denominados “CANELA”, “TAQUARUÇU” e “TAQUARI”, neste Município, descrita e caracterizada na petição inicial. (TOCANTINS, 1992, p. 862).

DECLARO, ainda, a INEFICÁCIA JURÍDICA dos títulos incidentes sobre a área objeto da lide, DETERMINANDO, por conseguinte, o CANCELAMENTO de todas as TRANSCRIÇÕES e REGISTROS IMOBILIÁRIOS existentes na mesma (TOCANTINS, 1992, p. 863).

Essa sentença gerou expectativas com relação à regularização fundiária nessa área. Porém, diante das muitas instabilidades, em 25 de setembro de 1992, o Ministério Público do Tocantins interpõe recurso por meio da Apelação Cível no 1.620/95 (TOCANTINS, 1997a; 1999a), levando essa ação discriminatória para julgamento, em segunda instância, no Tribunal de Justiça do Estado do Tocantins (TJ-TO). Por meio do efeito suspensivo, a sentença da citada ação discriminatória não pôde ser executada e a consequente regularização fundiária precisou aguardar o trânsito desse novo julgamento. Em face do efeito devolutivo, são inseridas novas demandas e, dessa maneira, o imbróglio fundiário se tornou mais evidente com as petições, juntadas aos autos, dos novos proprietários de terras, que alegavam possuir títulos adquiridos do estado do Tocantins. Ressalta-se que alguns dos expropriados readquiriram suas próprias terras nas alienações dos governos estaduais, no sentido de garantirem a propriedade, com registro em cartório, de títulos emitidos por intermédio de instituições governamentais.

A Apelação Cível no 1.620/95 (TOCANTINS, 1997a; 1999a), julgada em 18 de fevereiro de 1997, com certidão do trânsito em julgado do acórdão publicada em 2 de abril de 1997 e carta de sentença expedida em 26 de fevereiro de 1999, mantém as decisões sentenciadas na Ação Discriminatória no 335/82 (TOCANTINS, 1992), determinando que "diante do exposto e, acolhendo o parecer do órgão de cúpula Ministerial, CONHEÇO DO RECURSO por próprio e tempestivo, mas NEGO-LHE provimento, para manter a sentença guerreada" (TOCANTINS, 1997a, p. 331). Nota-se que, para aqueles que haviam feito a regularização ao comprarem imóveis do estado do Tocantins, não deveria haver o cancelamento das matrículas, pois “[...] se essas pessoas que pretendem se habilitar detêm títulos definitivos, com aquiescência do Estado, ora autor, naturalmente as suas transcrições estão a salvo" (TOCANTINS, 1997a, p. 331). 
Em 11 de março de 1999, valendo-se das partes dessas sentenças em que se definem a propriedade e o cancelamento das matrículas, é enviado, pela Procuradoria Geral do Estado do Tocantins (PGE-TO, 1999), ofício ao CRI de Palmas requerendo a abertura de uma nova matrícula, em nome do estado do Tocantins, na área da Ação Discriminatória no 335/82 (TOCANTINS, 1992). Nesse ato, é criada a matrícula de número 30.770, com 30.564,54 hectares (Figura 6), que engloba área superior aos aproximadamente 28.500 hectares citados na discriminatória, e, consequentemente, são canceladas, com amparo da referida sentença, todas as matrículas existentes na área, incluindo as emitidas com as alienações realizadas pelo próprio estado do Tocantins ou por instituições concernentes. ${ }^{12}$ Trata-se de outro ato de despossessão de terras em Palmas, que ocorre em virtude da interpretação arbitrária das sentenças da Ação Discriminatória nº 335/82 e da Apelação Cível nº 1.620/95 (TOCANTINS, 1992; 1997a; 1999a), já que, para o governo estadual (1999-2002), que correspondia ao terceiro mandato daquele que foi o primeiro governador (1989-1991), tais sentenças lhe valeram como reconhecimento de seu domínio sobre essas terras. Como assinala Rolnik (2015, p. 152), "é no interior desta trama jurídico-administrativa que se tecem os mecanismos de inclusão/exclusão na cidade".

Mesmo com sentenças julgadas em favor da regularização fundiária e com a emissão de títulos imobiliários por meio do próprio estado do Tocantins, o então governo estadual (1999-2002) determinou o apossamento dessas terras, com suas benfeitoras, que incluíam, em sua maioria, as moradias e os sítios de trabalho dos atingidos. A partir de 2001, são realizadas as desapropriações dessas benfeitorias. Como exemplo, citam-se o Decreto no 1.364, de 24 de novembro de 2001 (TOCANTINS, 2001), e o Decreto n 1.489, de 24 de abril de 2002 (TOCANTINS, 2002), que desapropriam benfeitorias nas terras associadas ao ato de despossessão de 1999. Como aponta Rolnik (2015, p. 151-152), “[...] o acesso e o uso da moradia e da terra são atravessados pelas estruturas de poder existentes na sociedade", que assumem uma postura de alteridade, especialmente em contexto de imprecisões em relação à posse e à propriedade, bem como em locais onde há crescente interesse pelas terras, que se tornam valiosas, como no caso das terras de uma capital estadual projetada.

\footnotetext{
12 O então governo do Tocantins alegou que o ITERTINS havia alienado, de forma irregular, terras que pertenciam ao estado do Tocantins e que, por isto, estava anulando estas alienações e os títulos daí decorrentes.
}

D 
Figura 6 - Palmas: área da matrícula 30.770 registrada em favor do estado do Tocantins em 1999.

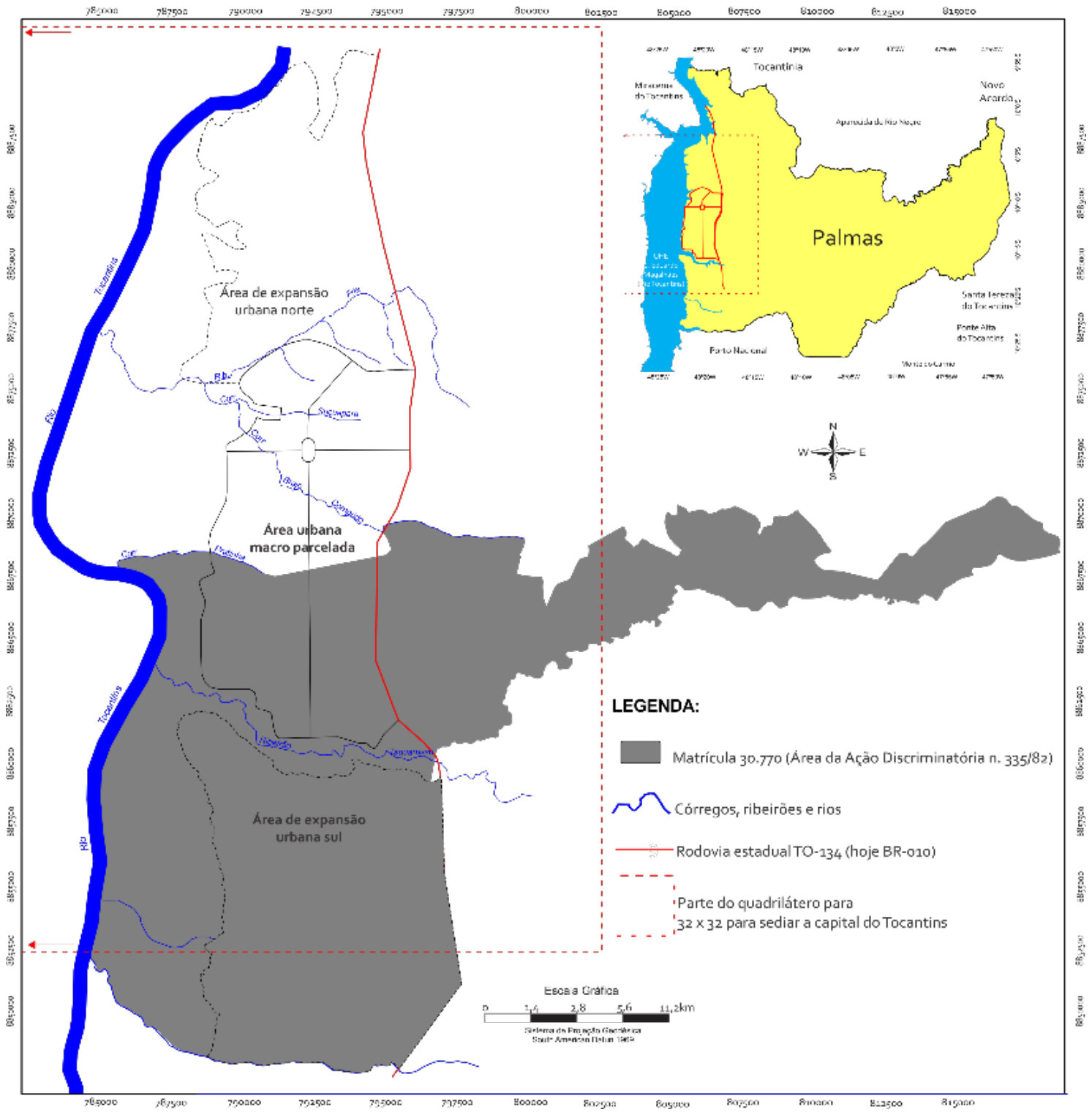

Fontes: PGE-TO (1999); CARTÓRIO... (2013); APPACCTO (2016).

\section{A quebra dos consensos arbitrários e das irresoluções fundiárias em Palmas}

Os impasses jurídicos travados entre o estado do Tocantins, que expropriou, e os antigos proprietários e posseiros de terras, que foram expropriados, ganham maior complexidade, a partir de 1999, com os novos cancelamentos de matrículas e o registro da matrícula n 30.770, em mais um ato de despossessão. Alheios aos impasses, os governos estaduais seguem negociando e expandindo loteamentos na área da Ação Discriminatória 
n 335/82 (TOCANTINS, 1992), por meio de ações diretas ou de seus delegados, a exemplo da CODETINS, da Orla S.A. e, mais recentemente, da TerraPalmas. ${ }^{13}$

Em março de 1999, logo após a criação da matrícula única, os atingidos que adquiriram suas próprias terras nas alienações do estado do Tocantins entram com a Ação Rescisória no 5000002-92.1999.827.0000 (TOCANTINS, 1999c), no TJ-TO, com o intuito de evitar a transcrição imobiliária de suas terras e a consequente incorporação destas ao patrimônio público. Esta ação não consegue alcançar os resultados esperados, e esses atingidos buscam outros mecanismos legais para que tenham o reconhecimento do registro de suas terras, como exemplifica o episódio que ficou conhecido como o "caso da aposentada" (BORGES, 2005).

Este caso se tornou emblemático, pois as terras dessa atingida, ocupadas desde 1948, com títulos registrados no CRI de Porto Nacional, sob matrículas de números 5.671 e 5.672, estavam, desde 1982, citadas na Ação Discriminatória n 335/82 (TOCANTINS, 1992), cuja finalidade é a regularização fundiária. Mas, em agosto de 1989, essas terras foram abrangidas, nas desapropriações judiciais vinculadas ao Decreto Legislativo nº 006/89 (TOCANTINS, 1989c; 1989k), e a atingida teve a posse provisória transferida para o estado do Tocantins. Em 1991, as matrículas de números 5.671 e 5.672 foram administrativamente canceladas e as terras foram englobadas na criação das matrículas n 2.760 (loteamento Santa Fé) e n ${ }^{\circ}$ 2.761 (loteamento Taquaruçu), em ato de despojo do executivo estadual. Ressalta-se que, nesse mesmo ano, o judiciário determinou a extinção da ação judicial de desapropriação, porque estava associada ao citado decreto legislativo e à consequente devolução da posse das terras aos atingidos. Como já exposto, a extinção dessa ação judicial não teve efeito sobre os atos administrativos do executivo estadual que cancelaram matrículas no CRI de Porto Nacional e criaram as seis matrículas no CRI de Palmas (incluindo-se a matrícula no 2.761). Em 1992, a sentença da Ação Discriminatória no 335/82 (TOCANTINS, 1992) é considerada procedente, pois identifica vícios nas transcrições imobiliárias, já que os títulos são derivados de paroquiais a non domino, e, por isto, determina o cancelamento dessas matrículas, apesar de ressalvar os direitos possessórios.

Nesse contexto de cancelamentos de matrículas, em 5 de abril de 1994, essa atingida compra suas próprias terras nas alienações realizadas pelo ITERTINS, que foram registradas sob a matrícula n² 21.111, no CRI de Palmas (BRASIL, 2005). Com a criação da matrícula no 30.770 , em 1999, essa atingida vê a sua referida matrícula cancelada por outro ato arbitrário do então governo do estado do Tocantins (1999-2002). Ciente do ato abusivo,

\footnotetext{
${ }^{13}$ O estado do Tocantins cria instituições (CODETINS e Companhia Imobiliária do Estado do Tocantins-TerraPalmas) e estabelece parcerias público-privadas (ORLA Participações e Investimentos S.A.) para o gerenciamento das terras tornadas públicas por via expropriatória.
}

D D Revista da Associação Nacional de Pós-graduação e Pesquisa em Geografia (Anpege).

D D p.31-70, V.15, n.27, mai./ago. 2019 
porque, a partir da compra em 1994, se torna detentora “[...] da propriedade por justo título, razão por que não poderia ter seu registro imobiliário cancelado" (BRASIL, 2005, p. 1), ela recorre ao TJ-TO, por meio de mandado de segurança. A sentença referente a este mandado, decretada em 2 de outubro de 2003, foi favorável ao estado do Tocantins, com sete votos a favor do expropriante e apenas três a favor da expropriada (ESTADO..., 2003).

Diante dessa derrota, recorre-se ao Superior Tribunal de Justiça (STJ), em Brasília, por meio de Recurso em Mandado de Segurança no 19.830-TO (2005/0052143-4) (BRASIL, 2005). Em 3 de novembro de 2005, o STJ dá ganho de causa à impetrante, afirmando que "viola direito líquido e certo o ato de autoridade que, à guisa de cumprimento de decisão judicial transitada em julgado, determina o cancelamento do registro de imóvel comprado diretamente do Estado, quando o decisum a que se visa dar cumprimento limitou-se aos imóveis adquiridos a non domino" (BRASIL, 2005, p.1), posto que a sentença da Apelação Cível no 1.620 (TOCANTINS, 1997a) resguarda os títulos definitivos emitidos com a anuência do estado do Tocantins. Consequentemente, a decisão impõe que o estado do Tocantins restabeleça a matrícula ${ }^{\circ} 21.111$, garantindo o direito de posse e de propriedade à atingida, porque "[...] não pode o Estado por vontade própria e unilateralmente, sem o devido processo legal, proceder o cancelamento do registro do imóvel da Impetrante após vendê-lo à mesma, sob pena de estar praticando um ato discordante dos princípios morais e éticos que se espera do ente estatal" (BRASIL, 2005, p. 3).

Essa decisão do STJ se estende a todos os atingidos em mesma situação, quer dizer, os que haviam adquirido imóveis nas alienações do estado do Tocantins e cujos registros não poderiam ser cancelados sem o devido processo legal. O contrário "[...] denota que existem interesses escusos de grupos que estão se aproveitando da situação para promover verdadeira rapina, confiscando criminosamente bens de quem detém a propriedade justa e legal” (BRASIL, 2005, p. 3). Ademais, essa sentença afirma que se está “[...] verificando um odioso confisco, através de atos ilegais da própria entidade estatal, para satisfazer a vontade inconfessável de grupos que aqui se estabelecem para encher as burras de dinheiro, à custa de bens alheios, nas portas do Judiciário" (BRASIL, 2005, p. 3-4).

Mesmo com o caráter incisivo dessa decisão do STJ, a resolução prática das disputas entre o estado do Tocantins e a atingida pouco avançou. Diante das irresoluções, em 9 de maio de 2006, recorre-se à Corregedoria Geral de Justiça, para que a ordem judicial de restabelecimento da matrícula no 21.111 seja cumprida. A Corregedoria Geral de Justiça dá ganho à impetrante, sendo enviado ao TJ-TO o Ofício Executório no 117/06-DRC, determinando que se faça cumprir o restabelecimento da matrícula da atingida. Em 
cumprimento, o TJ-TO envia despacho ao CRI de Palmas, que, em 30 de agosto de 2006, restabelece a matrícula nº 21.111 (CARTÓRIO..., 2007).

Com esse restabelecimento, para regularizar a situação fundiária dessas terras, faz-se necessária nova desapropriação, já que parte das terras (29,68 hectares) foi ocupada com os parcelamentos das quadras ARSEs 141 e 142 e com o autódromo Rubens Barrichello. Em 31 de outubro de 2006, o estado do Tocantins lança o Decreto n² 2.876/2006 (TOCANTINS, 2006), encaminhado pela ação judicial de desapropriação nº 2007.0000.4455-3/0, que envolve as terras da matrícula $n^{\circ} 21.111$.

Porém, mesmo tomando providências para cumprir a decisão judicial no "caso da aposentada", o estado do Tocantins entra com o Mandado de Segurança n 27.524-TO (2008/0171007-1) (BRASIL, 2009a), no STJ, afirmando que a Corregedoria Geral de Justiça não tem competência para determinar a devolução das terras e alegando que “[...] o ato de cancelamento dos registros imobiliários se deu em cumprimento da decisão exarada nos autos da Ação Discriminatória no 335/82, que declarou os ditos imóveis como pertencentes ao domínio público estadual" (BRASIL, 2009a, p. 5). Em 4 de agosto de 2009, o STJ decide “[...] por unanimidade, negar provimento ao recurso ordinário em mandado de segurança [...]" no 27.524-TO (2008/0171007-1) (BRASIL, 2009a, p. 1), afirmando que a Corregedoria Geral de Justiça não estava alterando a sentença dada, mas ordenando que fosse cumprida: “[...] no caso dos autos, não há abusividade ou ilegalidade no ato objeto do mandamus, que nada mais fez do que preservar os direitos daqueles que não foram atingidos pelo decisum [...] não há falar em relativização da coisa julgada, mas preservação dela" (BRASIL, 2009a, p. 8).

Dadas as imprecisões ainda constantes, coube, em 2009, o Pedido de Providência n ${ }^{\circ}$ 200910000059144/09 (BRASIL, 2009b) ao Conselho Nacional de Justiça (CNJ), em Brasília. Neste, é requerido que a Corregedoria do CNJ intime o CRI de Palmas a restabelecer as matrículas que foram canceladas, conforme as decisões judiciais, de modo a retificar a origem da matrícula e sua vinculação à matrícula n 30.770 , por sua vez vinculada às sentenças da discriminatória e não às matrículas de números 2.760 (loteamento Santa Fé) e 2.761 (loteamento Taquaruçu), criadas sem o devido procedimento legal. Em novembro de 2009, é emitido parecer favorável, baseado nos autos da Ação Discriminatória n 335/82 (TOCANTINS, 1992) e no Auto Circunstanciado de Inspeção Preventiva (BRASIL, 2009c) realizado pela Corregedoria do $\mathrm{CNJ}$.

D

D Devista da Associação Nacional de Pós-graduação e Pesquisa em Geografia (Anpege).

D D p.31-70, V.15, n.27, mai./ago. 2019. 
[...] cumpre agora, administrativamente, determinar o restabelecimento de todas as outras matrículas que foram atingidas indevidamente pelo cancelamento, cumprindo apenas que se retifique, por averbação, que a origem da propriedade do transmitente, o estado do Tocantins, seja a matrícula 30.770 , e não a 2.760 [...], tendo em vista o decidido na Ação Discriminatória 335/82 (BRASIL, 2009b, p. 76-77).

Nesse auto, são verificadas e confirmadas as irregularidades no cancelamento de "aproximadamente 427 matrículas das que foram canceladas [e que] tinham como titular o Estado [...]", apontando que, "nesses casos, as matrículas não devem ser canceladas, mas apenas retificada a origem da aquisição do domínio pelo Estado de Tocantins, que deixou de ser aquisição derivada para se tornar aquisição originária da ação requerida" (BRASIL, 2009c, p. 4). Ademais, comprovou-se que

O Estado de Tocantins vendeu os imóveis aos requerentes, cujos títulos foram devidamente matriculados e registrados, sem que tivesse sua propriedade por qualquer meio questionada, restando indubitável que a venda consolidou-se, de modo que qualquer interesse na sua retomada só poderá ser efetivada por nova desapropriação, sem afetar assim a legislação vigente e os princípios de direito (BRASIL, 2009c, p. 5).

É importante esclarecer que havia 160 matrículas habilitadas, quando a Ação Discriminatória n 335/82 (TOCANTINS, 1992) foi instaurada, porém, com as alienações, dações e doações realizadas pelos governos do Tocantins, após a imissão provisória de posse nas ações judiciais de desapropriação e após a criação das seis matrículas nos atos de despossessão de 1990 a 1991, estas terras foram parceladas, resultando nestas 427 matrículas a serem restauradas.

Assim, em 18 de janeiro de 2010, a Corregedoria do CNJ aprova o parecer emitido e determina que o CRI de Palmas restabeleça todos os registros de imóveis cancelados, cujas aquisições têm como origem o estado do Tocantins, independente de ação judicial, e o cancelamento de todos os registros sobrepostos (BRASIL, 2010). O estado do Tocantins ainda tentou anular a decisão do CNJ por meio do Mandado de Segurança n 28.915, impetrado no Ministério Público Federal (BRASIL, 2011). Este mandado foi negado, e o estado do Tocantins teve de iniciar as providências para acatar as decisões judiciais em favor desses atingidos.

Em paralelo, desenrola-se a Ação de Execução para Entrega de Coisa Certa n 679/02 (TOCANTINS, 1996), impetrada, em 1996, por um grupo de atingidos que não recebeu os imóveis acordados nas dações de pagamento indenizatórias, sendo um associado às desapropriações executadas por via judicial e seis vinculados às desapropriações executadas por procedimentos administrativos via Procuradoria Geral do Estado do Tocantins. 
Desse modo, os atingidos que seguiram com suas lutas contra as arbitrariedades, os abusos de poder e as irresoluções na liberação das terras para a implantação de Palmas têm sentenças favoráveis no judiciário, restando ao estado do Tocantins acatar tais deliberações. Contudo, as condições para o atendimento dessas sentenças em favor dos atingidos são bastante complexas. No que diz respeito à Ação de Execução para Entrega de Coisa Certa no 679/02 (TOCANTINS, 1996), de 2009 a 2010, quatro dos atingidos envolvidos mediam novos acordos de dação de terras em pagamento indenizatório com o governo do estado do Tocantins, sendo recebidos 177 lotes em quadras da capital. Em 2016, são fechados outros acordos de dação de terras em pagamento indenizatório com mais dois desses atingidos, que recebem 50 lotes em quadras da capital (TOCANTINS, 2013a; TOCANTINS, 2016a, 2016b). Não há informação sobre o atingido associado à desapropriação executada por via judicial (TOCANTINS, 1996).

No caso do Pedido de Providência no 200910000059144/09 (BRASIL, 2010), ocorre, no CRI de Palmas, o restabelecimento das matrículas canceladas conforme a ordem judicial em 2010, incluindo-se a matrícula nº 21.111 já reestabelecida (CARTÓRIO..., 2007). A partir disto, duas situações ficam evidentes: na primeira, os atingidos puderam retomar, ao mesmo tempo, a propriedade e a posse de suas terras, porque estas não tinham sido negociadas pelos governos do estado do Tocantins ou instituições e empresas afins; na segunda, os atingidos retomam apenas a propriedade, porque as terras tinham sido negociadas e, portanto, se encontravam em posse dos adquirentes. Nessa situação, as terras desses atingidos foram envolvidas em novas desapropriações, encaminhadas pelos poderes executivos estadual e municipal, para advir, na sequência, a regularização fundiária para os adquirentes que detêm a posse.

Como já citado, há o Decreto n².876/2006 (TOCANTINS, 2006), que envolve as terras da matrícula no 21.111 , cuja ação judicial foi finalizada em 23 de novembro de 2010, com a assinatura do Termo de Acordo de Desapropriação Amigável, Dação em Pagamento Indenizatória e Outras Avenças (TOCANTINS, 2010). Neste termo, o estado do Tocantins se compromete com indenizações monetárias acrescidas de juros e correções e com a devolução da posse de 163,92 hectares restantes das terras não alienadas, obrigando-se, ainda, a registrar, junto ao CRI de Palmas, o microparcelamento das quadras ARSEs 151 e 152 em nome do espólio da atingida (TOCANTINS, 2010). Trata-se de espólio, porque, depois de anos de lutas, a aposentada em questão faleceu, em 2009.

Em 22 de fevereiro de 2013, é emitido o Decreto nº 4.746/2013 (TOCANTINS, 2013b), encaminhado pela ação judicial de desapropriação de número 0001894.90.2013.4.01.4300,

D

D Revista da Associação Nacional de Pós-graduação e Pesquisa em Geografia (Anpege).

D D p.31-70, V.15, n.27, mai./ago. 2019. 
impetrada em 22 abril de 2013, que envolve os atingidos vinculados à matrícula de número 17.748, anteriormente parte da matrícula de número R-2-271 (fazenda Taquari), ocupada com o loteamento Jardim Aureny III e com o Aeroporto de Palmas, administrado pela Empresa Brasileira de Infraestrutura Aeroportuária (Infraero), que recebeu área de 2.373,99 hectares, doada pelo estado do Tocantins (TOCANTINS, 1997b; TOCANTINS, 1999b). Após cinco anos de negociações, em 2018, foi assinado o acordo que finalizará a desapropriação, após os trâmites legais. Neste, o estado do Tocantins abre mão da desapropriação da integralidade da área e a União permuta uma área já ocupada pelas instalações aeroportuárias por outra contígua a um dos lados da propriedade de matrícula nº 17.748 (BRASIL, 2018).

O Decreto n 954/2015 (PALMAS, 2015), de 26 de janeiro de 2015, é encaminhado pela ação judicial de desapropriação no 5001847-18.2002.827.2729, e envolve as terras dos atingidos associados à matrícula de número 20.290, parte da antiga matrícula R-1-M-8.416 (Lote $n^{\circ} 3$ ), ocupada com uma parcela do loteamento Jardim Taquari. Por conta de desacordos, a referida ação judicial é encaminhada por meio da Apelação Cível $\mathrm{n}^{\circ}$ 0013290-36.2015.827.0000 (TOCANTINS, 2016c), que, em 17 de agosto de 2016, é finalizada com a homologação do acordo entre as partes envolvidas. Neste, o atingido teve devolvida uma área não ocupada, correspondente ao valor de $\mathrm{R} \$ 16.457 .180,00$, e foi proposta a indenização de $\mathrm{R} \$ 65.168 .146,62$ pela parte alienada, dividida entre o estado do Tocantins e o município de Palmas, na proporção de $\mathrm{R} \$ 31.339 .875$, 00 e R \$ 33.828.271,62, respectivamente. $\mathrm{O}$ estado do Tocantins pagou quatro milhões em dinheiro e o restante com imóveis em dação em pagamento indenizatória. O município de Palmas deduziu do valor a ser pago o montante de $\mathrm{R} \$ 1.411 .000,00$ referentes a débitos de Imposto sobre a Propriedade Predial e Territorial Urbana (IPTU), e o restante foi pago com imóveis em dação em pagamento indenizatória (TOCANTINS, 2016c).

Diante dessas novas desapropriações de terras ainda associadas à implantação de Palmas, a situação, em 2018 (quando se finaliza a coleta de dados desta pesquisa), revela que, das 15 propriedades rurais atingidas pelo Decreto n 651/89 (TOCANTINS, 1989d), oito foram desapropriadas, uma teve parte desapropriada e parte devolvida ao atingido, duas foram devolvidas aos atingidos, três seguiam com ações em tramitação na justiça e sobre uma não se obteve informação. Das 23 propriedades rurais atingidas pelo Decreto n 655/89 (TOCANTINS, 1989e), treze foram desapropriadas, três foram devolvidas aos atingidos, três seguem com ações em tramitação na justiça e sobre quatro não se obtiveram informações. Sobre as três propriedades rurais atingidas pelo Decreto n 665/89 (TOCANTINS, 1989f), não se obtiveram informações. As cinco propriedades rurais atingidas pelo Decreto $\mathrm{n}^{\circ}$ $666 / 89$ (TOCANTINS, 1989g) foram desapropriadas. Das 94 propriedades e posses rurais 
atingidas pelo Decreto Legislativo nº06/89 (TOCANTINS, 1989c), de 49, cujas ações foram executadas por via judicial, 17 foram desapropriadas, 31 foram devolvidas aos atingidos e uma segue com ação tramitando na justiça; de oito, cujas ações foram executadas por procedimentos administrativos (TOCANTINS, 1996), seis foram desapropriadas, uma teve parte desapropriada e parte devolvida ao atingido, e uma foi devolvida ao atingido; e três, cujas ações de desapropriação foram executadas após as últimas decisões judiciais, tiveram partes das propriedades desapropriadas e partes devolvidas aos atingidos (TOCANTINS, 2006; 2010; 2013a; 2013b; 2016a; 2016b; PALMAS, 2015).

Ressalta-se que sobre 34 propriedades e posses rurais não se obtiveram informações (Tabela 3). Desse modo, 35\% das propriedades e posses rurais atingidas foram desapropriadas; $3,6 \%$ tiveram partes desapropriadas e partes devolvidas aos atingidos; $26,4 \%$ foram devolvidas aos atingidos; $5 \%$ seguem envolvidas em ações judiciais; e sobre 30\% não se obtiveram informações de sua situação, em 2018 (Tabela 3, Figura 7).

As terras envolvidas nas desapropriações para a implantação de Palmas, em sua porção centro-norte, que contém parte da área macroparcelada e a área de expansão urbana norte do projeto da capital, já haviam sido regularizadas pelo INCRA $(1979 ; 1981)$ e foram atingidas, em sua maioria, pelos quatro decretos de desapropriação do estado do Tocantins (TOCANTINS, 1989d; 1989e; 1989f; 1989g). Por conta disso, a maior parte dessas terras foi desapropriada, cabendo devoluções apenas em áreas muito distantes das áreas de macroparcelamento e de expansão urbana norte (Figura 7). Em sua porção centro-sul, que contém parte da área de macroparcelamento e a área de expansão urbana sul do projeto, a maioria dessas terras se encontrava em processo de regularização fundiária por meio da Ação Discriminatória ${ }^{\circ}$ 335/82 (TOCANTINS, 1992; BRASIL, 2010) e foram atingidas por ações de desapropriação mediadas pelo Decreto Legislativo no 006/89 (TOCANTINS, 1989c), sejam as executadas por via judicial, sejam as executadas por procedimentos administrativos.

Por essas razões e outras associadas, sobretudo, aos atos de despossessão, às alienações e doações de terras realizadas pelo estado do Tocantins e instituições concernentes, e aos descumprimentos dos acordos de dação de terras em pagamento indenizatório, a maior parte destas terras foi envolvida em imbróglios jurídicos travados entre o expropriante e os expropriados, cujos resultados culminam na Ação de Execução para Entrega de Coisa Certa no 679/02 (TOCANTINS, 1996) e no Pedido de Providência no 200910000059144/09 (BRASIL, 2009b). Ambos os processos judiciais resultaram na entrega indenizatória e na devolução de terras aos expropriados (Figura 7). Porém, no Pedido de Providência no 200910000059144/09 (BRASIL, 2009b), além da devolução da maior parte dessas terras aos

D

D D Revista da Associação Nacional de Pós-graduação e Pesquisa em Geografia (Anpege).

D $D$

p.31-70, V.15, n.27, mai./ago. 2019. 
atingidos, tem-se a necessidade de novas desapropriações nas áreas alienadas ou doadas pelo estado do Tocantins (TOCANTINS, 2006; 2010; 2013b; PALMAS, 2015).

Tabela 3 - Palmas: situação, em 2018, das propriedades e posses rurais atingidas nas desapropriações de terras iniciadas de 1989 a 1991, de 1992 a 1993 e de 2006 a 2015.

\begin{tabular}{|c|c|c|c|c|c|c|c|c|c|c|}
\hline Decretos & & 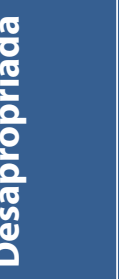 & $\stackrel{2}{2}$ & 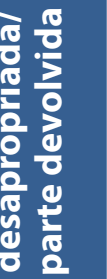 & & $\begin{array}{l}0 \\
0 \\
0 \\
0 \\
0 \\
0 \\
0\end{array}$ & & 递 & & 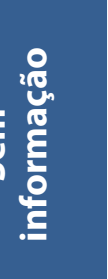 \\
\hline Decreto n. $651 / 89$ & 8 & $5,7 \%$ & 1 & $0,7 \%$ & 2 & $1,4 \%$ & 3 & $2,1 \%$ & 1 & $0,7 \%$ \\
\hline Decreto n. 655/89 & 13 & $9,4 \%$ & -- & -- & 3 & $2,1 \%$ & 3 & $2,1 \%$ & 4 & $2,9 \%$ \\
\hline Decreto n. 665/89 & -- & -- & -- & -- & -- & -- & -- & -- & 3 & $2,1 \%$ \\
\hline Decreto n. 666/89 & 5 & $3,6 \%$ & -- & -- & -- & -- & -- & -- & -- & -- \\
\hline Decreto n. 006/89¹ & 17 & $12,1 \%$ & -- & -- & 31 & $22,2 \%$ & 1 & $0,7 \%$ & 34 & $24,3 \%$ \\
\hline Decreto n. 006/89² & 6 & $4,2 \%$ & 1 & $0,7 \%$ & 1 & $0,7 \%$ & -- & -- & -- & -- \\
\hline Decreto n. 2.876/2006 & -- & -- & 1 & $0,7 \%$ & -- & -- & -- & -- & -- & -- \\
\hline Decreto n. 4.746/2013 & -- & -- & 1 & $0,7 \%$ & -- & -- & -- & -- & -- & -- \\
\hline Decreto n. 954/2015 & -- & -- & 1 & $0,7 \%$ & -- & -- & -- & -- & -- & -- \\
\hline Total ${ }^{3}$ & 49 & $35 \%$ & 5 & $3,6 \%$ & 37 & $26,4 \%$ & 7 & $5 \%$ & 42 & $30 \%$ \\
\hline
\end{tabular}

Fontes: TOCANTINS (1989d; 1989e; 1989f; 1989g; 1989c; 1989; 1989I; 1989m; 1990; 1991; 2006; 2010; 2013a; 213b; 2016a; 2016b); PALMAS (2015); TERRAPALMAS (2015); APPACCTO (2016). ${ }^{1}$ Desapropriações executadas por via judicial. ${ }^{2}$ Desapropriações executadas por procedimentos administrativos. ${ }^{3}$ Com aproximações decimais. 
Figura 7 - Palmas: situação das áreas atingidas nas desapropriações de terras dos governos estadual e municipal de 1989 a 2018.

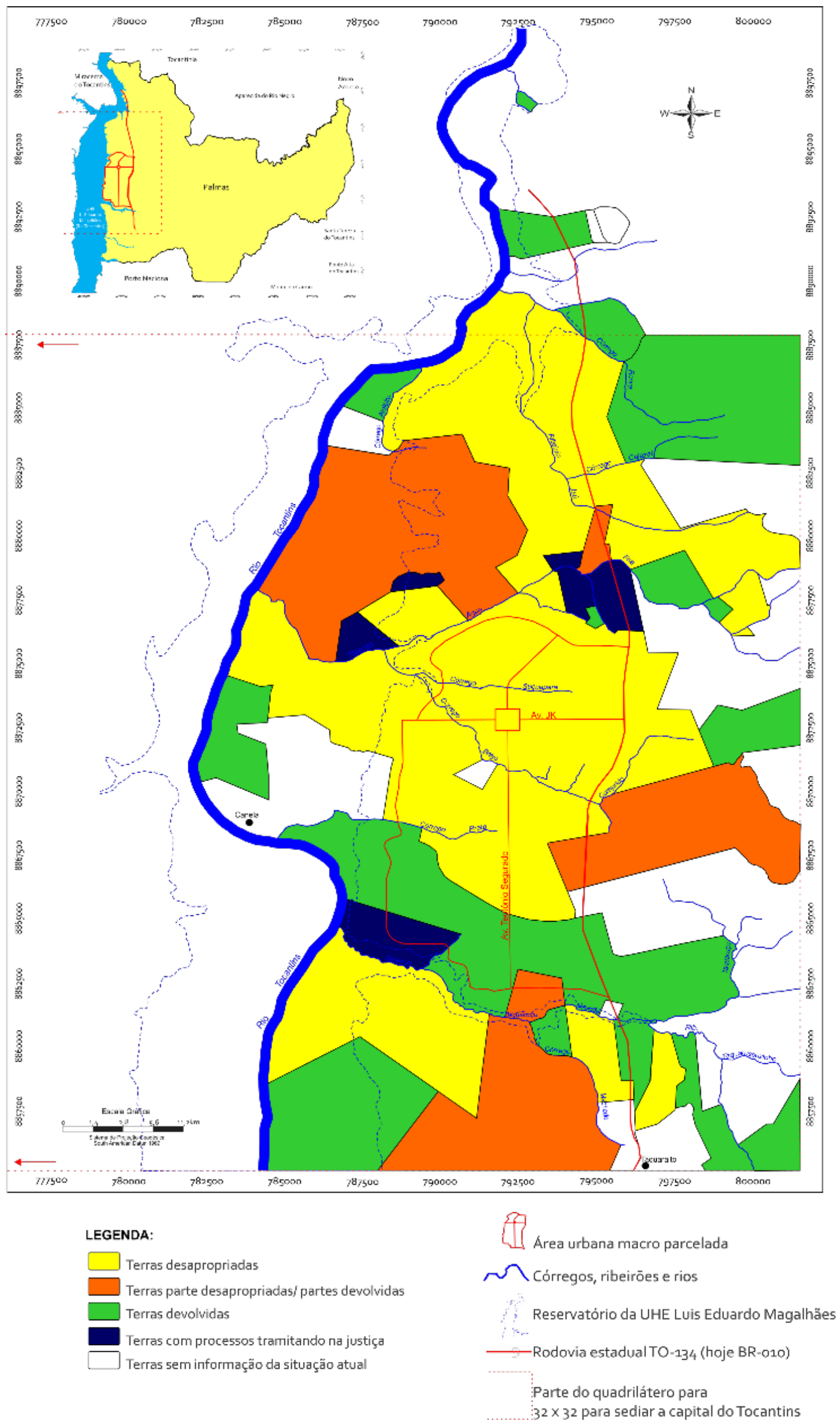

Fontes: TOCANTINS (1989d; 1989e; 1989f; 1989g; 1989c; 1989i; 1989l; 1989m; 1990; 1991; 2006; 2010; 2013a; 213b; 2016a; 2016b); PALMAS (2015); TERRAPALMAS (2015); APPACCTO (2016).

D

D D D Revista da Associação Nacional de Pós-graduação e Pesquisa em Geografia (Anpege).
p.36-66, V.15, n.27, mai./ago. 2019.

D $D$ 
Assim, na área de macroparcelamento do projeto urbano, com seus 11.084,47 hectares, a maior parte das terras foi desapropriada, mas parte foi devolvida aos atingidos; na área de expansão urbana norte, com seus 4.625 hectares, a maior parte das terras foi desapropriada, outra parte foi devolvida aos atingidos; na área de expansão urbana sul, com seus 4.869 hectares, a maior parte das terras foi devolvida aos atingidos, mas uma parte foi desapropriada (Figura 7). Ressalta-se que, por conta de algumas irresoluções, parte dessas terras ainda está envolvida em ações que tramitam na justiça, e, por conta das dificuldades de acesso aos dados, sobre parte destas terras não se obtiveram informações (Figura 7).

\section{Considerações finais}

A análise da apropriação das terras - ou seja, do espaço - para a construção de Palmas, capital do estado do Tocantins, ganha um conteúdo social inegável, pois se constitui histórica e espacialmente por meio de práticas socioespaciais de sujeitos que intervieram no espaço de maneira contraditória e conflituosa, cabendo, por fim, a mediação do poder judiciário.

Como aponta Carlos (2011a; 2011b), os sujeitos da apropriação/produção/reprodução e o próprio espaço revelam-se historicamente, por meio das práticas socioespaciais destes sujeitos e da própria morfologia espacial resultante. Dessa forma, o entendimento das desapropriações e das despossessões de terras para a implantação dessa capital implica pensar no conteúdo dos processos constitutivos deste espaço urbano, quer dizer, em sua natureza e em seus significados políticos, econômicos e, propriamente, sociais, posto que o modo de apropriação se realiza pelos usos, pelos valores e pelos sentidos.

Nessa perspectiva, a compreensão dessas práticas socioespaciais leva em conta a análise das categorias conceituais apropriação, uso e valor (de uso e de troca). A análise, nessa problemática concreta, revela apropriações, usos e valores diretamente associados à dominação política e à acumulação de capital fundiário/imobiliário, que expressam nitidamente os sentidos da "acumulação por espoliação" (HARVEY, 2004, p. 127), inclusive com práticas predatórias e bárbaras de despossessão, mas também vinculados à realização da vida que revela o sentido humano da apropriação/produção/reprodução do espaço e da cidade. Além disso, tais apropriações, usos e valores revelam os sentidos das contradições e dos conflitos que levam às lutas sociais travadas entre o expropriante e os expropriados, reforçando o sentido social dessa apropriação/produção/reprodução e não apenas o seu sentido como “[...] condição da reprodução do poder ou do capital” (CARLOS, 2011a, p. 67).

Essa realidade concreta expressa que a apropriação das terras rurais e sua conversão em terras urbanas implicam na sobreacumulação de valores fundiários e imobiliários pelos 
sujeitos desta apropriação, mormente o Estado e o capital. Mas, com as devoluções de terras e com as dações em pagamento nos acordos indenizatórios firmados mais recentemente, os atingidos passam a ter importante participação no mercado de terras. Desse modo, a posição desses atingidos é redefinida de expropriado para agente fundiário urbano. Trata-se de uma nova contradição, porque, até então, essas terras estavam envolvidas nas lutas sociais de um grupo de expropriados, para quem eram terras de uso, de trabalho, de manutenção da vida.

Mas o atual momento histórico é o da "extensão do mundo da mercadoria" (CARLOS, 2011a, p. 60), ${ }^{14}$ e, pela mediação ou cooptação do mercado imobiliário, essas terras são transformadas em mercadorias e ganham centralidade no processo de acumulação. Como aponta Carlos (2011b, p. 91), “[...] o solo urbano, sob a determinação da produção, permite a realização do valor, ${ }^{15}$ quando disposto por seu proprietário no mercado imobiliário [...]", tornando-se mercadoria. No período recente, prevalece a lógica do valor de troca e não do valor de uso, pois essas terras são plenamente inseridas na lógica de reprodução do capital imobiliário. Dessa maneira, coloca-se a apropriação do espaço, que é privada, em primeiro plano (CARLOS, 2011a; 2011b), e o sentido humano e social da cidade, em segundo plano.

Em contrapartida, o estado do Tocantins, o sujeito da dominação política, tem o seu patrimônio fundiário reduzido em Palmas, podendo ser ainda mais afetado pelas ações que seguem na justiça. Como aponta Carlos (2008, p. 33), o espaço urbano de uma cidade, a exemplo do de Palmas, é "[...] um produto concreto de relações sociais historicamente determinadas", e, mais especificamente, um produto de uma história profundamente contraditória, em que o Estado pode ser afetado, tendo seu poder diminuído, mas o capital (neste caso, por meio de agentes imobiliários) encontra mecanismos de reprodução ampliada, com a incorporação dessas terras ao mercado imobiliário. Isto gera uma assimetria entre o poder político (relativamente reduzido) e o poder econômico (alargado), com complexas consequências com relação aos interesses de grande parte da população citadina.

14 Para Carlos (2011a, p. 60-61), “a extensão do mundo da mercadoria” significa “[...] a expansão da propriedade privada do solo urbano e da terra, que transforma a cidade inteira em mercadoria a ser vendida no mercado".

15 De acordo com Carlos (2011b, p. 91), “[...] assumindo, sob o capitalismo, a forma mercadoria, a cidade é nessa condição fonte de valor (de uso e de troca)".

D 


\section{Referências bibliográficas}

1. ADVOCACIA GERAL DO ESTADO. Ofício nº 054/91, de 25 de fevereiro de 1991. Palmas, 1991a.

2. Ofício nº 087/91, de 11 de março de 1991. Palmas, 1991b.

3. APPACCTO - Associação de Proprietários e Posseiros da Área Destinada à Construção da Capital do Tocantins. Ata da assembleia geral de fundação da Associação dos Proprietários e Posseiros da Área Destinada à Construção da Capital do Tocantins - APPACCTO, realizada em 28 de junho de 1989. Porto Nacional, 1989a.

4. Proposta de negociação entregue ao governo do estado do Tocantins, em 26 de setembro de 1989. Porto Nacional, 1989b. Mimeografado.

5 . Abaixo-assinado entregue ao governador do estado, de 24 de novembro de 1989. Porto Nacional, 1989c. Mimeografado.

6. Manifesto entregue à população. Palmas, 1990. Mimeografado.

7. Dados sobre os processos de desapropriações para a implantação de Palmas. Palmas, 2016. Mimeografado.

8. BORGES, D. Títulos cancelados causam prejuízo. Jornal do Tocantins, Palmas, 15 maio 2005.

9. BRASIL. Lei $\mathbf{n}^{\circ} \mathbf{6 0 1}$, de 18 de setembro de 1850 . Dispõe sobre as terras devolutas do Império. Rio de Janeiro, 1850.

10. Decreto-Lei no 3.365, de 21 de junho de 1941. Dispõe sobre desapropriações por utilidade pública. Rio de Janeiro, 1941.

11. Lei 6.383, de 7 de dezembro de 1976. Dispõe sobre o processo discriminatório de terras devolutas da União, e dá outras providências. Brasília, 1976.

12. Constituição da República Federativa do Brasil. Brasília: Senado Federal, 1988.

13. Superior Tribunal de Justiça (Segunda Turma). Recurso em mandado de segurança nº 19.830 - TO (2005/0052143-4) - Ementa/Acórdão, de 3 de novembro de 2005. Diário de Justiça, Brasília, 14 nov. 2005, p. 233.

14. . Superior Tribunal de Justiça (Primeira Turma). Recurso em mandado de segurança no 27.524 - TO (2008/0171007-1) - Ementa/Voto, 4 de agosto de 2009. Diário de Justiça, Brasília, 19 ago. 2009a.

15. Conselho Nacional de Justiça. Corregedoria. Pedido de Providências $\mathbf{n}^{\mathbf{o}}$ 200910000059144. Referência: Ação discriminatória nº 335/82 do Estado do Tocantins. Brasília, 4 nov. 2009b. 
16. . Conselho Nacional de Justiça. Corregedoria. Auto Circunstanciado de Inspeção Preventiva, de 23 de novembro de 2009. Portaria no 131, de 12 de junho de 2009. Brasília, 2009c.

17. Conselho Nacional de Justiça. Pedido de Providência no 200910000059144, de 18 de janeiro de 2010. Decisão/Ofício nº 31/2010. Brasília, 2010.

18. Ministério Público Federal. Mandado de Segurança no 28.915, de 7 de junho de 2011. (Pedido de Providências nº 0005914-60.2009.2.00.0000). Brasília, 2011.

19. Tribunal Regional Federal da Primeira Região. Seção Judiciária do Estado do Tocantins. $1^{\text {a }}$ Vara. Ação Ordinária no 0001894.90.2013.4.01.4300 - Sentença Tipo “A”, de 28 de fevereiro de 2018. Palmas, 2018.

20. CARLOS, A. F. A. A (re)produção do espaço urbano. São Paulo: Edusp, 2008.

21. Da "organização" à "produção" do espaço no movimento do pensamento geográfico. In: CARLOS, A. F. A.; SOUZA, M. L.; SPOSITO, M. E. B. A produção do espaço urbano. São Paulo: Contexto, 2011a, p. 53-73.

22. A condição espacial. São Paulo: Contexto, 2011b.

23. CARTÓRIO DE REGISTRO GERAL DE IMÓVEIS. Comarca de Taquarussu do Porto. Edital de loteamento de Palmas, de 21 de novembro de 1989. Diário Oficial do Estado do Tocantins, Palmas, n. 25, 1989.

24. Comarca de Palmas. Ofício nº 001/91 a 005/91, de 1 de abril de 1991. Palmas, 1991.

25 . Comarca de Palmas. Certidão de Inteiro Teor do Imóvel no 21.111, expedida em 16 de janeiro de 2007. Palmas, 2007.

26. Comarca de Palmas. Certidão de Inteiro Teor do Imóvel no 30.770, expedida em 9 de agosto de 2013. Palmas, 2013.

27. ESTADO invade terras de aposentada. Mira Jornal, Palmas, 28 set. a 4 out. 2003. Informe Especial.

28. GOIÁS. Lei no $\mathbf{1 0 . 4 1 9}$, de $1^{\circ}$ de janeiro de 1988. Dispõe sobre a criação do município de Taquarussu do Porto e dá outras providências. Diário Oficial do Estado de Goiás, Goiânia, 27 jan. 1988.

29. GOVERNADOR age ilegalmente nas desapropriações em Palmas. O Jacumã, Porto Nacional, p. 6, out. 1989

30. GRUPOQUATRO. Projeto da capital do estado do Tocantins: plano básico/memória. Palmas: Governo do Estado do Tocantins; Novatins, 1989.

D 
31. HARVEY, D. A justiça social e a cidade. São Paulo: Hucitec, 1980 [1973].

32. O novo imperialismo. São Paulo: Edições Loyola, 2004.

33. A produção capitalista do espaço. São Paulo: Annablume, 2005.

34. IBGE - Instituto Brasileiro de Geografia e Estatística. Carta topográfica Miracema/Miranorte. Brasília, s/d. Escala: 1:250.000.

35. INCRA - Instituto Nacional de Colonização e Reforma Agrária. Água Fria. Porto Nacional, 1979. Mapa físico. Escala: 1:100.000.

36. Loteamento Canela. Porto Nacional, 1981. Mapa físico. Escala: 1:20.000.

37. IPUP - Instituto de Planejamento Urbano de Palmas. Caderno de revisão do Plano Diretor. Caderno de revisão de Palmas Sul. Palmas, 2002.

38. LEFEBVRE, H. De l'État: les contradictions de l'État moderne. Paris: Union Générale d'Éditions, 1978 (v. 4).

39. La production de l'espace. Paris: Anthropos, 1981 [1972].

40. MARX, M. Cidade no Brasil. Terra de quem? São Paulo: Edusp; Nobel, 1991.

41. PALMAS. Lei $\mathbf{n}^{\mathbf{0}} \mathbf{2 8}$, de 29 de dezembro de 1989. Transfere a sede do município de Taquarussu do Porto para Palmas. Diário Oficial do Estado do Tocantins, Palmas, n. 28, 1989.

42. Lei $\mathbf{n}^{\circ}$ 33, de 13 de fevereiro de 1990. Estabelece nos limites do município os distritos de Palmas e dá outras providências. Diário Oficial do Estado do Tocantins, Palmas, n. 34, 1990.

43. Decreto de 4 de maio de 2010. Declara de utilidade pública, para fins de desapropriação, uma área de terras rural denominada de lote único, da Fazenda Barra da Tiuba. Diário Oficial de Palmas, Palmas, n. 30, 2010.

44. Decreto $\mathbf{n}^{\circ}$ 954, de 26 de janeiro de 2015. Altera o Decreto 951, de 21 de janeiro de 2015 na parte que especifica e adota outras providências. Palmas, 2015.

45. PGE-TO - Procuradoria Geral do Estado do Tocantins. Ofício no ${ }^{075}$, de 11 de março de 1999. Palmas, 1999.

46. ROLNIK, R. Guerra dos lugares: a colonização da terra e da moradia na era das finanças. São Paulo: Boitempo, 2015.

47. TERRAPALMAS. Relação das ações desapropriatórias propostas para a implantação da capital. Palmas, 2015. Mimeografado. 
48. TOCANTINS. Medida Provisória $\mathbf{n}^{\circ} .009$, de $1^{\circ}$ de janeiro de 1989. Diário Oficial do Estado do Tocantins, Palmas, n. 1, 1989a.

49. Lei nº 009, de 23 de janeiro de 1989. Declara de utilidade pública, para efeito de desapropriação, área de terras descrita em memorial e dá outras providências. Diário Oficial do Estado do Tocantins, Palmas, n. 4, 1989 b.

50. Decreto Legislativo n $^{\circ}$ 006, de 9 de fevereiro de 1989. Dispõe sobre a localização da capital definitiva do estado do Tocantins e dá outras providências. Diário Oficial do Estado do Tocantins, Palmas, n. 12, 1989c.

51. Decreto $\mathrm{n}^{\circ}$ 651, de 13 de abril de 1989. Dispõe sobre as áreas de terras que desapropria e dá outras providências. Diário Oficial do Estado do Tocantins, Palmas, n. 9, 1989d.

52. Decreto $\mathbf{n}^{\circ}$ 655, de 13 de abril de 1989. Dispõe sobre as áreas de terras que desapropria e dá outras providências. Diário Oficial do Estado do Tocantins, Palmas, n. 9, 1989e.

53. Decreto $\mathrm{n}^{\circ}$ 665, de 27 de abril de 1989. Dispõe sobre as áreas de terras que desapropria e dá outras providências. Diário Oficial do Estado do Tocantins, Palmas, n. 10, 1989 f.

54. Decreto $\mathrm{n}^{\circ}$ 666, de 27 de abril de 1989. Dispõe sobre as áreas de terras que desapropria e dá outras providências. Diário Oficial do Estado do Tocantins, Palmas, n. 10, 1989g.

55. Decreto $\mathrm{n}^{\circ}$ 667, de 27 de abril de 1989. Dispõe sobre as áreas de terras que desapropria e dá outras providências. Diário Oficial do Estado do Tocantins, Palmas, n. 10, 1989h.

56. Comarca de Porto Nacional. 2a Vara Cível. Autos de desapropriação por utilidade pública. Porto Nacional, 1989 (Vários autos judiciais, com números distintos).

57. Comarca de Porto Nacional. 2a Vara Cível. Autos de desapropriação por utilidade pública n. 2.099/89, de 18 de agosto de 1989. Porto Nacional, 1989j.

58. Comarca de Porto Nacional. 2a Vara Cível. Autos de desapropriação por utilidade pública n. 2.106/89, 21 de agosto de 1989. Porto Nacional, 1989k.

59. . Comarca de Taquarussu do Porto. 2a Vara Cível. Autos de desapropriação por utilidade pública. Taquarussu do Porto, 19891 (Alguns autos judiciais, com números distintos).

60. . Comarca de Palmas. 2a Vara Cível. Autos de desapropriação por utilidade pública. Palmas, 1989m (Vários autos judiciais, com números distintos).

61. Edital de concorrência pública n. 026/89 - alienação de imóveis, de 28 de novembro de 1989. Diário Oficial do Estado do Tocantins, Palmas, n. 25, 1989n.

62. . Comarca de Palmas. $2^{\text {a }}$ Vara Cível. Autos de desapropriação por utilidade pública. Palmas, 1990 (Alguns autos judiciais, com números distintos).

D D D Revista da Associação Nacional de Pós-graduação e Pesquisa em Geografia (Anpege).

D D p.31-70, V.15, n.27, mai./ago. 2019 
63. . Comarca de Palmas. 2a Vara Cível. Autos de desapropriação por utilidade pública. Palmas, 1991 (Vários autos judiciais, com números distintos).

64. . Comarca de Palmas. 2a Vara Cível. Sentença da Ação Discriminatória nº 057/90, de 4 de maio de 1992. Diário de Justiça do Tocantins, Palmas, n. 147, 1992.

65. Comarca de Palmas. $1^{\text {a }}$ Vara da Fazenda Pública. Autos de Ação de Execução para Entrega de Coisa Certa no 679/02 (5001610-81.2002.827.2729), de 22 de abril de 1996. Palmas, 1996.

66. Tribunal de Justiça do Estado do Tocantins. 1a Turma Julgadora da Câmara Cível. Ementa: Apelação cível n. 1.620/95 - Ação discriminatória nº 335/82 - Recurso conhecido e improvido. Diário de Justiça do Tocantins, Palmas, n. 477, 3 mar. 1997a.

67. Lei n. 937, de 23 de outubro de 1997. Autoriza o Chefe do Poder Executivo a doar áreas de terras, nesta Capital, à Empresa Brasileira de Infraestrutura Aeroportuária - INFRAERO e dá outras providências. Diário Oficial do Estado do Tocantins, Palmas, n. 641, 1997b.

68. Tribunal de Justiça do Estado do Tocantins. Apelação Cível no 1.620/95: Ação Discriminatória no 335/82 - Carta de Sentença, de 14 de janeiro de 1999. Diário de Justiça do Tocantins, Palmas, n. 669, 1999a.

69. Lei n. 1044, de 27 de janeiro de 1999. Altera a Lei n. 937, de 23 de outubro de 1997. Diário Oficial do Estado do Tocantins, Palmas, n. 767, 1999b.

70. Tribunal de Justiça do Estado do Tocantins. 1a Câmara Cível. Ação Rescisória ${ }^{\circ}$ 5000002-92.1999.827.0000, de 22 de março de 1999. Palmas, 1999c.

71. Decreto $\mathbf{n}^{\circ}$ 1.364, de 27 de novembro de 2001. Declara de utilidade pública, para fins de desapropriação, as benfeitorias que especifica. Diário Oficial do Estado do Tocantins, Palmas, n. 1.112, 2001.

72. TOCANTINS. Decreto $\mathbf{n}^{\circ} \mathbf{1 . 4 8 9}$, de 24 de abril de 2002. Declara de utilidade pública, para fins de desapropriação, as benfeitorias que especifica. Diário Oficial do Estado do Tocantins, Palmas, n. 11.81, 2002 .

73. Decreto $\mathbf{n}^{\mathbf{0}} \mathbf{2 . 8 7 6}$, de 31 de outubro de 2006. Declara de utilidade pública, para fim de desapropriação, a área de terras que especifica. Diário Oficial do Estado do Tocantins, Palmas, n. 2.279, 2006.

74 . Termo de acordo de desapropriação amigável, dação em pagamento indenizatória e outras avenças que entre si celebram, de um lado o estado do Tocantins e de outro lado o espólio de Terezinha Alves Evangelista, de 23 de novembro de 2010. Palmas, 2010. 
75. Comarca de Palmas. $3^{\text {a }}$ Vara dos Feitos das Fazendas e Registros Públicos. Autos de Ação de Execução para Entrega de Coisa Certa no 679/02 (5001610-81.2002.827.2729). Oficio 226/2013, de 18 de outubro de 2013. Palmas, 2013a.

76. Decreto $\mathbf{n}^{\circ}$ 4.746, de 22 de fevereiro de 2013. Declara de utilidade pública, para fins de desapropriação, a área de terra rural que especifica e adota outras providências. Diário Oficial do Estado do Tocantins, Palmas, n. 3.821, $2013 \mathrm{~b}$.

77. Comarca de Palmas. $3^{\text {a }}$ Vara dos Feitos das Fazendas e Registros Públicos. Autos de Ação de Execução para Entrega de Coisa Certa no 679/02 (5001610-81.2002.827.2729). Acordo extrajudicial, de 18 de maio de 2016. Palmas, 2016a.

78 . Comarca de Palmas. $3^{\text {a }}$ Vara dos Feitos das Fazendas e Registros Públicos. Autos de Ação de Execução para Entrega de Coisa Certa no 679/02 (5001610-81.2002.827.2729). Acordo extrajudicial, de 18 de dezembro de 2016. Palmas, 2016b.

79 . Tribunal de Justiça do Tocantins. 1a Câmara Cível. Apelação cível n. 001329036.2015.827.0000 - Decisão, de 17 de agosto de 2016. Palmas, 2016c.

80. SASSEN, S. Expulsões: brutalidade e complexidade na economia global. São Paulo: Paz e terra, 2016.

81. VELASQUES, A. B. A. A concepção de Palmas (1989) e sua condição moderna. Tese (Doutorado em Urbanismo). Universidade Federal do Rio de Janeiro, Rio de Janeiro, 2010, $246 f$.

D D p.31-70, V.15, n.27, mai./ago. 2019 